


\section{GATT STANDARDS CODE ACTIVITIES OF THE NATIONAL INSTITUTE OF STANDARDS AND TECHNOLOGY - 1989}

\section{JoAnne R. Overman}

\author{
U.S. DEPARTMENT OF COMMERCE \\ Natlonal Institute of Standards \\ and Technology \\ Standards Code and Information Program \\ Offlce of Standards Servlces \\ Galthersburg, MD 20899
}

Aprll 1990

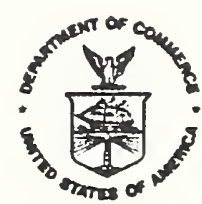

U.S. DEPARTMENT OF COMMERCE Robert A. Mosbacher, Secretary NATIONAL INSTITUTE OF STANDARDS AND TECHNOLOGY

Dr. John W. Lyone, Director 

This report describes the GATT Standards code activities conducted by the Standards Code and Information Program, National Institute of standards and Technology (NIST), for calendar year 1989. It also presents statistics covering the 10 years (1980 through 1989) of the Standards Code's implementation in the United States. NIST responsibilities include operating the U.S. GATT inquiry point for information on standards and certification activities and the technical office for non-agricultural products; notifying the GATT Secretariat of proposed U.S. Federal Government standards-based rules that might significantly affect trade; assisting U.S. industry with standards-related trade problems; and responding to inquiries about proposed foreign and U.S. regulations.

Key Words: certification information; GATT Standards Code; notifications; proposed foreign regulations; standards information; technical assistance 



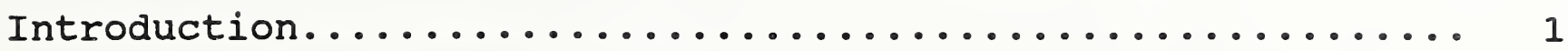

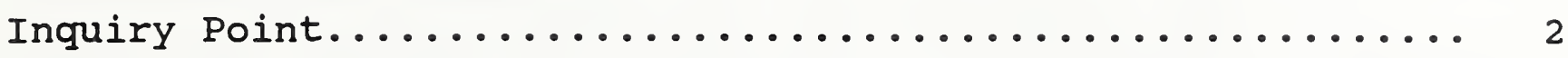

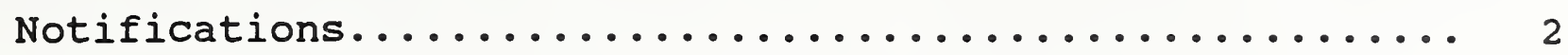

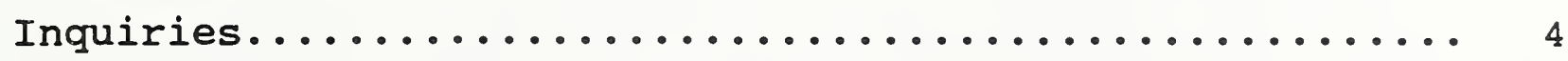

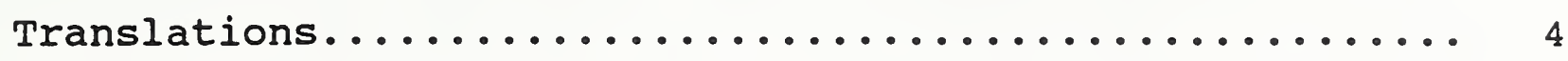

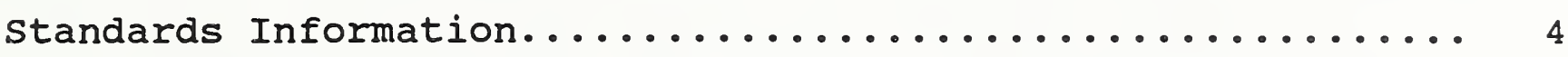

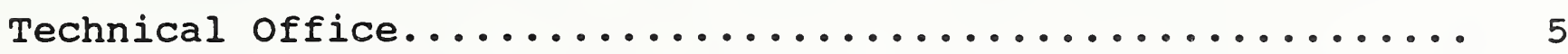

Comment Handling.......................... 6

Comment Periods........................... 7

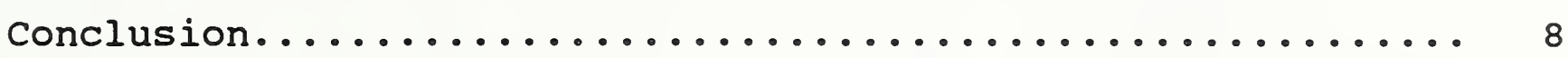

standards Code signatories...................... g

Tables

Table I and II Ten-Year statistics .................. 10

Table III Number of Notifications Issued in 1989...... 11

Table IV List of U.S. Notifications................. 12

Table $\mathrm{V}$ List of Foreign Notifications............ 13

Appendix A Key-Word-Out-of-Context (KWOC) Index of

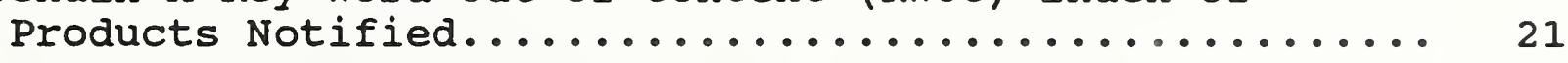

Appendix B Number of Enquiries by Signatories ........ 45 



\section{INTRODUCTION}

\section{Ten Years of the Standards code}

The end of 1989 marked the tenth anniversary of the implementation of the Standards code in the United states. During 1980 through 1989, thousands of notifications, requests, and GATT hotline calls were received. Specifically: 2,297 $(2,034$ foreign, 263 U.S.) notifications; $3,433(2,837$ U.S., 596 foreign) requests for standards Code information; and 3,928 hotline calls were processed. Other related statistics covering part of the 10-year period include the following: 45 comments were made through the Government on proposed foreign technical regulations; 125 foreign documents were translated; and of all the signatory countries, Japan had the most notifications for four of the 10 years. (See tables I and II for details.) Five meetings of persons responsible for information exchange (GATT inquiry point representatives) were held during this period.

There were 32 signatories when the standards code first went into effect. Today there are 39,29 of which have actively implemented the code in their countries. The other 10 signatories have either not ratified the Agreement, established an inquiry point for standards information, reported any proposed government mandatory regulations (see "Standards code

Signatories"), or some combination of the foregoing. The code is administered by the secretariat of the General Agreement on Tariffs and Trade (GATT) in Geneva, Switzerland.

In 1986, a new round of multilateral trade negotiations began the Uruguay Round - to evaluate the standards code and to make recommendations for improvement. These negotiations, scheduled to conclude in 1990, will likely result in the adoption of several proposals to improve or expand the scope of the standards code.

The Trade Agreements Act of 1979 ratified the United States' accession to the GATT Standards code. Under Title IV of the Act the NIST office of Standards Services (OSS) is responsible for several provisions which relate to the establishment of a U.S. inquiry point, $\bar{l}$ a standards information center, and a technical office for non-agricultural products.

This report summarizes standards code activities conducted by the Standards code and Information (SCI) Program for calendar year 1989. These functions are performed within the traditional framework of NIST's standards-related programs.

1 The standards code requires that each signatory provide an inquiry point to answer all requests for information about technical regulations, standards, and rules of certification. 


\section{INQUIRY POINT}

\section{Notifications}

Signatories of the standards code must notify the GATT secretariat of all proposed government regulations and certification procedures that might significantly affect international trade. The secretariat, in turn, disseminates the notifications to all other signatories. As the official U.S. GATT inquiry point for information on standards and certification activities, SCI notifies the secretariat of proposed U.S. Federal Government rules that might significantly affect trade. SCI also receives foreign notifications through the GATT Secretariat and disseminates them, along with supplementary information, to appropriate U.S. companies and industry groups. SCI responds to inquiries about foreign and U.S. notifications, provides copies of the proposed regulations, and arranges for translations of foreign standards. SCI also assists in developing comments on the impact on U.S. industry of proposed foreign regulations and transmits them to the foreign government concerned.

In 1989 the GATT secretariat issued 328 notifications, the most ever issued in a single year. Twenty-three signatories reported at least one proposed regulation. (See table III.) Finland had the most notifications with 39. Fourteen other signatories Austria, Belgium, Canada, Czechoslovakia, Denmark, EEC, Japan, New Zealand, Norway, Philippines, Romania, Sweden, United States, and Yugoslavia - each reported 10 or more proposed regulations.

An official in the office of the U.S. Trade Representative (USTR), based in Geneva, receives notifications from the GATT secretariat and cables them to the United States. The notifications, all of which are available in English, include the name of the country proposing the regulation; the assigned TBT/Notification number; a brief description of the regulation; and the final date for comments. In order to provide wide access to this information in the United states, all foreign notifications are published in the Commerce Business Daily and several other U.S. publications. SCI maintains a computerized database on all GATT notifications and a telephone GATT hotline where up-to-date notification information can be obtained. The hotline number is (301) 975-4041. (not toll free).

Proposed U.S. Regulations

All proposed U.S. Government rules (mandatory standards or certification systems), including proposed revisions, are published in the Federal Register by the responsible Federal agency. SCI staff regularly review the Register to identify those proposed regulations that should be notified to the GATT 
Secretariat and send notices directly to the GATT Secretariat via telefax.

In 1989, 15 proposed U.S. regulations, covering such products as motor vehicles, appliances, and foods, were reported. The originating agencies are shown below. (See table IV for listing of specific products by agency.)

\section{Agency}

Agriculture, Department of (USDA) Bureau of Alcohol, Tobacco \& Firearm Commerce, Department of (DOC) Environmental Protection Agency (EPA) Food and Drug Administration (FDA) National Highway Traffic Safety Administration (NHTSA)
No. of 1989 Notifs.

$\begin{array}{lr}\text { (BATF) } & 1 \\ & 1 \\ & 1 \\ & 1 \\ & 6 \\ \text { Total } & \frac{5}{15}\end{array}$

\section{Proposed Foreign Regulations}

The GATT Secretariat in 1989 issued 313 notifications from countries other than the United States. (See table V.) The foreign regulations covered a wide variety of products, including data communication networks, toys, food, household appliances, safety belts, and dental chairs. SCI maintains a Key-Word-outof-Context (KWOC) index for all products that are the subject of foreign notifications. (See Appendix A for the 1989 index.) (KWOC is an indexing method in which keywords, in this instance product names, appear as headings on a separate line.) The KWOC index is used to identify regulations that may be of interest to individuals who have expressed interest in specific products.

SCI regularly sends foreign notifications to members of the Industry Functional Advisory Committee on standards (IFAC) ${ }^{2}$ and several other groups and specific individuals to serve their information needs and to allow them to disseminate this information to others. SCI sends copies of all foreign notifications to the American National Standards Institute for subsequent publication in its biweekly ANSI Reporter.

2 The IFAC is comprised of Government-appointed individuals from private industry engaged in standards-related activities. It advises the Department of Commerce and USTR on trade matters, the operation of any adopted trade agreements and other subjects related to U.S. trade policy. 


\section{Inquiries}

SCI responded to 376 domestic and foreign letter and telephone requests for GATT notification information (305 U.S., 71 foreign) in 1989. Many requestors asked for copies of more than one regulation. In addition to requests for specific regulations, many individuals asked for general information on the standards code. SCI responds to such requests by sending an information package consisting of the latest issue of its newsletter, tbt news, a list of recent foreign notifications, brochures describing the standards code, and ordering information for the Commerce Business Daily.

In 1989, the regulations most often requested concerned telecommunications equipment, electrical equipment, food products, and household appliances. In addition, 402 individuals called the GATT hotline for up-to-date information on foreign notifications.

\section{Translations}

SCI requests the text of all proposed foreign regulations which are subjects of notification. Signatory countries are required to supply copies of the regulations through their inquiry points. of the 286 regulations received in 1989, 181 were in languages other than English. SCI coordinates a service to obtain an English translation on request, of any proposed regulation in a foreign language. The cost of translation is paid by the requestor; if more than one request is received for the same translation, the cost is divided equally among requestors. In 1989, SCI received nine requests for translations of 10 regulations and standards-related documents.

\section{STANDARDS INFORMATION}

The National Center for Standards and Certification Information (NCSCI) is the national repository for standards documentation. NCSCI supports GATT inquiry point activities by supplying information concerning both domestic and foreign standards. The information center, established in 1965, provides government, industry and the public with information on standards, regulations, certification programs, and related activities that affect trade and commerce.

NCSCI maintains a microform and/or hard copy collection of engineering standards and specifications, test methods, regulations, certification rules, directories, reference books and special publications. In 1989, NCSCI staff responded to more than 5,000 requests from all over the world on the existence, source, and availability of standards and related documents. Twenty-eight of the 39 signatories contacted the Center for information. (See Appendix B.) NCSCI also responds to 
trade-related queries regarding regulations or other requirements imposed by foreign countries that affect the export of U.S. manufactured products.

In 1989, SCI published and NCSCI distributed the Directory of International and Regional organizations Conducting standardsRelated Activities (NIST SP 767) containing information on 338 organizations which conduct standardization, laboratory accreditation, or other standards-related activities. (NIST SP 767 supersedes NBS SP 649.) NCSCI also distributed the newly published Directory of U.S. Private sector Product certification programs (NIST SP 774) (which supersedes NBS SP 703) to provide information on 132 U.S. private sector organizations engaged in product certification activities.

\section{TECHNICAL OFFICE}

The Technical office, established by the Trade Agreements Act of 1979, is responsible for providing technical support related to non-agricultural products. Office functions include:

a) participation in standards-related conferences; b) technical assistance to the International Trade Administration of the Department of Commerce and the office of the U.S. Trade Representative in developing proposals to enhance the standards Code; c) preparation of special reports on standards issues; and d) coordination of comments on proposed foreign regulations.

Highlights of the 1989 Technical office activities are as follows:

- Technical office staff served as a voting member representing the U.S. Government interests in the coordinating committee for the Organization for Economic Co-operation and Development (OECD) Tractor Testing in the United States.

- Through a subcommittee of the Industry Functional Advisory Committee, staff members worked with industry representatives to produce a proposal, "Systems for the Accreditation or Approval of Testing Laboratories, Inspection or Quality systems Registration Bodies," to amend the standards code. This proposal, if adopted, would ensure that national treatment is not denied by the criteria used for accreditation or approval purposes.

- Technical office staff published An Update of U.S. participation in International standards Activities (NISTIR 894124), which presents updated information on the current level of U.S. participation in the two major non-governmental international standardization bodies: ISO and IEC. This report updates NBSIR 88-3698, A Review of U.S. Participation in International standards Activities. 
- Office staff also prepared a report addressing processes and production methods (PPMs) and their relationship to trade, the Standards code, and traditional product standards used in international commerce. The report, Trade Implications of Processes and Production Methods (NISTIR 90-4265) provides background information on PPMs, a suggested definition, and the possible extension of their application from the agricultural sector to industrial products.

- Staff members participated in the initiation of bilateral discussions with Mexican standards officials to further mutual understanding of the principles of the standards code. Staff also provided in-depth information to encourage non-signatory nations, such as Israel, to sign the standards code.

- In a related area - the EC 1992 Single Internal Market - staff members worked closely with other Government agencies to inform U.S. industry of EC 1992 standards-related activities. Several staff members participated in the EC 1992 Work Group on standards, Testing and Certification, chaired by the International Trade Administration's Office of European Community Affairs. Office staff made 20 presentations on EC 1992 standards development activities to interested U.S. industry groups. A staff member served on a panel during the public hearings held in July on EC standards, testing and certification activities and monitored and provided information on developments in the harmonization of European single market standardization, certification, and testing programs and laboratory accreditation activities.

\section{Comment Handling}

A major objective of the standards code is to allow exporters, Government agencies, and other interested parties to comment on proposed foreign regulations which they think would unjustifiably impede exports. SCI provides the text of proposed foreign regulations on request and encourages the submission of comments if a regulation appears to create unnecessary trade barriers. SCI transmits comments to the appropriate foreign government and coordinates any follow-up activity. In 1989, SCI received and processed formal comments on six foreign regulations: Japan cosmetics (89.71); Korea - computers and peripherals (88.203) and cosmetics (89.228); Norway - batteries and accumulators (89.143); Sweden - light duty trucks (89.84); and United Kingdom - oral snuff (89.221). Additional informal comments are frequently made by industry representatives who become aware of proposed regulations, often even before they are officially notified through the GATT. The notification system can often serve as a back-up mechanism to ensure awareness of foreign developments. 


\section{Comment Periods}

So that signatories will have adequate time to receive the text of a regulation (and to have it translated if necessary), review it, and prepare comments, the standards code recommends a comment period of at least 60 days. If the comment period is insufficient (e.g., due to late receipt of an English version or complicated technical issues), the technical office will request that the issuing country extend the comment period. In 1989, seven such requests were made to the notifying Party. Of the seven requests, three were granted. Many extensions are requested so that individuals can translate and study the regulation without necessarily indicating an intention to comment.

The average length of the comment period ${ }^{3}$ in 1989 was 47 days for U.S. regulations and 50 days for foreign regulations. The average length of the comment period, by U.S. agency, is shown below.

$\begin{array}{lrl}\text { BATF } & 32 & \text { days } \\ \text { DOC } & 9 & \text { days } \\ \text { EPA } & 55 & \text { days } \\ \text { FDA } & 59 & \text { days } \\ \text { NHTSA } & 41 & \text { days } \\ \text { USDA } & 53 & \text { days }\end{array}$

Comment periods for foreign regulations ranged from none at all to 374 days. The average length of comment period by country was:

$\begin{array}{lllr}\text { Austria } & 76 \text { days } & \text { Japan } & 61 \text { days } \\ \text { Belgium } & 34 \text { days } & \text { Korea } & 59 \text { days } \\ \text { Canada } & 27 \text { days } & \text { New Zealand } & 63 \text { days } \\ \text { Czechoslovakia } & 31 \text { days } & \text { Norway } & 80 \text { days } \\ \text { Denmark } & 49 \text { days } & \text { Philippines } & 28 \text { days } \\ \text { EEC } & 62 \text { days } & \text { Romania } & 43 \text { days } \\ \text { Finland } & 69 \text { days } & \text { Singapore } & 0 \text { days } \\ \text { France } & 0 \text { days } & \text { Sweden } & 56 \text { days } \\ \text { Germany } & 77 \text { days } & \text { Switzerland } & 88 \text { days } \\ \text { India } & 21 \text { days } & \text { United Kingdom } & 24 \text { days } \\ \text { Ireland } & 18 \text { days } & \text { Yugoslavia } & 43 \text { days }\end{array}$

3 Number of calendar days between the date the notification was issued by the GATT secretariat and the closing date for comments. 
SCI continues to work with U.S. industry to assist in addressing standards-related trade problems and to assure wide distribution of relevant notifications of proposed foreign regulations which might affect trade. Requests for further information, suggestions on how the service might be made more useful, or comments on subjects covered in this report should be directed to:

Standards Code and Information Program

National Institute of Standards and Technology

Administration Building, Room A629

Gaithersburg, MD 20899

(301) 975-4037

For specific standards-related information from NCSCI, call (301) $975-4038,-4040$, or -4036 .

For up-to-date information on foreign proposed regulations, call the GATT Hotline (301) 975-4041. 
Argentina (a)

Austria

Belgium

Brazil (b)

Canada

Chile (b)

Czechoslovakia

Denmark

Egypt (b)

European Economic

Community (EEC)

Finland

France

Federal Republic of Germany

Greece (b)

Hong Kong

Hungary

India

Ireland

Italy
Japan

Korea

Luxembourg (b)

Mexico (b)

Netherlands

New Zealand

Norway

Pakistan (b)

Philippines

Portugal (b)

Romania

Rwanda (c)

Singapore

Spain

Sweden

Switzerland

Tunisia

United Kingdom

United States

Yugoslavia

(a) - the country has not yet ratified the standards code and has not reported any proposed regulations to the GATT secretariat.

(b) - the country has not reported any proposed regulations to the GATT Secretariat.

(c) - the country has not established an inquiry point for standards information and has not reported any proposed regulations to the GATT secretariat. 


$$
\text { TEN-YEAR STATISTICS (1980 - 1989) }
$$

TABLE I

\begin{tabular}{|c|c|c|c|c|c|c|}
\hline YEAR & & $\begin{array}{l}\text { F NOTIFS. } \\
(F / D)^{\star}\end{array}$ & $\# 0$ & $\begin{array}{l}\text { REQUESTS } \\
(\mathrm{D} / \mathrm{F})\end{array}$ & $\begin{array}{l}\text { U.S. REGS } \\
\text { REPORTED }\end{array}$ & $\begin{array}{r}\text { HOTL } \\
\text { CAI }\end{array}$ \\
\hline 1980 & 99 & $(67 / 32)$ & 29 & $(N / A)$ & 32 & \\
\hline $\begin{array}{l}1981 \\
\text { 198 }\end{array}$ & 295 & $(204 / 91)$ & 366 & $(281 / 85)$ & 91 & 0 \\
\hline 1982 & 202 & $(177 / 25)$ & 478 & $(407 / 71)$ & 25 & 996 \\
\hline 1983 & 255 & $(240 / 15)$ & 458 & $(405 / 53)$ & 15 & 591 \\
\hline 1984 & 223 & $(195 / 28)$ & 385 & $(310 / 75)$ & 28 & 428 \\
\hline 1985 & 197 & $(183 / 14)$ & 367 & $(296 / 71)$ & 14 & 321 \\
\hline 1986 & 216 & $(203 / 13)$ & 314 & $(249 / 65)$ & 13 & 322 \\
\hline 1987 & 199 & $(193 / 6)$ & 291 & $(246 / 45)$ & 6 & 443 \\
\hline 1988 & 283 & $(259 / 24)$ & 369 & $(309 / 60)$ & 24 & 425 \\
\hline 1989 & 328 & $(313 / 15)$ & 376 & $(305 / 71)$ & 15 & 402 \\
\hline TOTAL & 2297 & $7(2034 / 263)$ & $3 \longdiv { 4 3 3 }$ & $(2837 / 596)$ & $\overline{263}$ & $\overline{3928}$ \\
\hline
\end{tabular}

TABLE II

\begin{tabular}{ccccc} 
YEAR & $\begin{array}{c}\text { OF SIGNATORIES } \\
\text { REPORTING }\end{array}$ & $\begin{array}{l}\text { OF SIGNA- } \\
\text { TORIES }\end{array}$ & $\begin{array}{c}\text { OF } \\
\text { COMMENTS }\end{array}$ & $\begin{array}{c}\text { \# OF } \\
\text { TRANSLATIONS }\end{array}$ \\
\hline
\end{tabular}

$\begin{array}{lllrr}1980 & 13 \text { U.S. ** } & 32 & 0 & 0 \\ 1981 & 20 \text { U.S. } & 32 & 3 & 0 \\ 1982 & 20 \text { JAPAN } & 36 & 3 & 0 \\ 1983 & 22 \text { JAPAN } & 37 & 13 & 2 \\ 1984 & 22 \text { JAPAN } & 37 & 2 & 5 \\ 1985 & 20 \text { CANADA } & 38 & 5 & 43 \\ 1986 & 19 \text { JAPAN } & 38 & 3 & 42 \\ 1987 & 20 \text { SWEDEN } & 39 & 4 & \frac{9}{125} \\ 1988 & 25 \text { SWEDEN } & 39 & 6 & \frac{6}{45} \\ 1989 & 23 \text { FINLAND } & 39 & & \end{array}$

* F - FOREIGN

D - DOMESTIC

** Signatory with the most notifications 
Notifying Countries and

Number of GATT Notifications Issued in 1989

Signatory

Austria

Belgium

Canada

Czechoslovakia

Denmark

EEC

Finland

France

Germany

India

Ireland

Japan

Korea

New Zealand

Norway

Philippines

Romania

Singapore

Sweden

switzerland

United Kingdom

United states

Yugoslavia
Number of

Notifications

13

18

19

27

18

11

39

2

1

4

2

20

1

14

12

11

31

1

37

4

5

15

23

Total 328 
TABLE IV

\section{List of U.S. Notifications}

$\begin{array}{ll}\text { TBT /NOTIF. \# } & \text { AGENCY } \\ 89.2 & \text { FDA }(275) * \\ 89.33 & \text { NHTSA }(276) \\ 89.66 & \text { USDA }(278) \\ 89.67 & \text { BATF }(277) \\ 89.72 & \text { FDA }(279) \\ 89.93 & \text { DOC }(280) \\ 89.117 & \text { NHTSA }(281) \\ 89.141 & \text { FDA }(282) \\ 89.185 & \text { FDA }(283) \\ 89.222 & \text { EPA }(284) \\ 89.248 & \text { FDA }(285) \\ 89.257 & \text { FDA }(286) \\ 89.259 & \text { NHTSA }(287) \\ 89.270 & \text { NHTSA }(288) \\ 89.321 & \text { NHTSA }(289)\end{array}$

PRODUCT

FOODS

TIRES FOR PASSENGER CARS

TURKEY HAM PRODUCTS

ALCOHOLIC BEVERAGES

SULFITES

TOY FIREARMS

AIR BRAKE SYSTEMS

CERAMIC PRODUCTS

HUMAN \& VETERINARY DRUG PRODUCTS

DISHWASHERS, CLOTHES WASHERS \& DRYERS

FOOD PRODUCTS-LABELING

HORMONE CONTAINING DRUG PRODUCTS

GLAZING MATERIALS

ROOF CRUSH RESISTANCE

AIR BRAKE SYSTEMS

*CONTROL NUMBER 

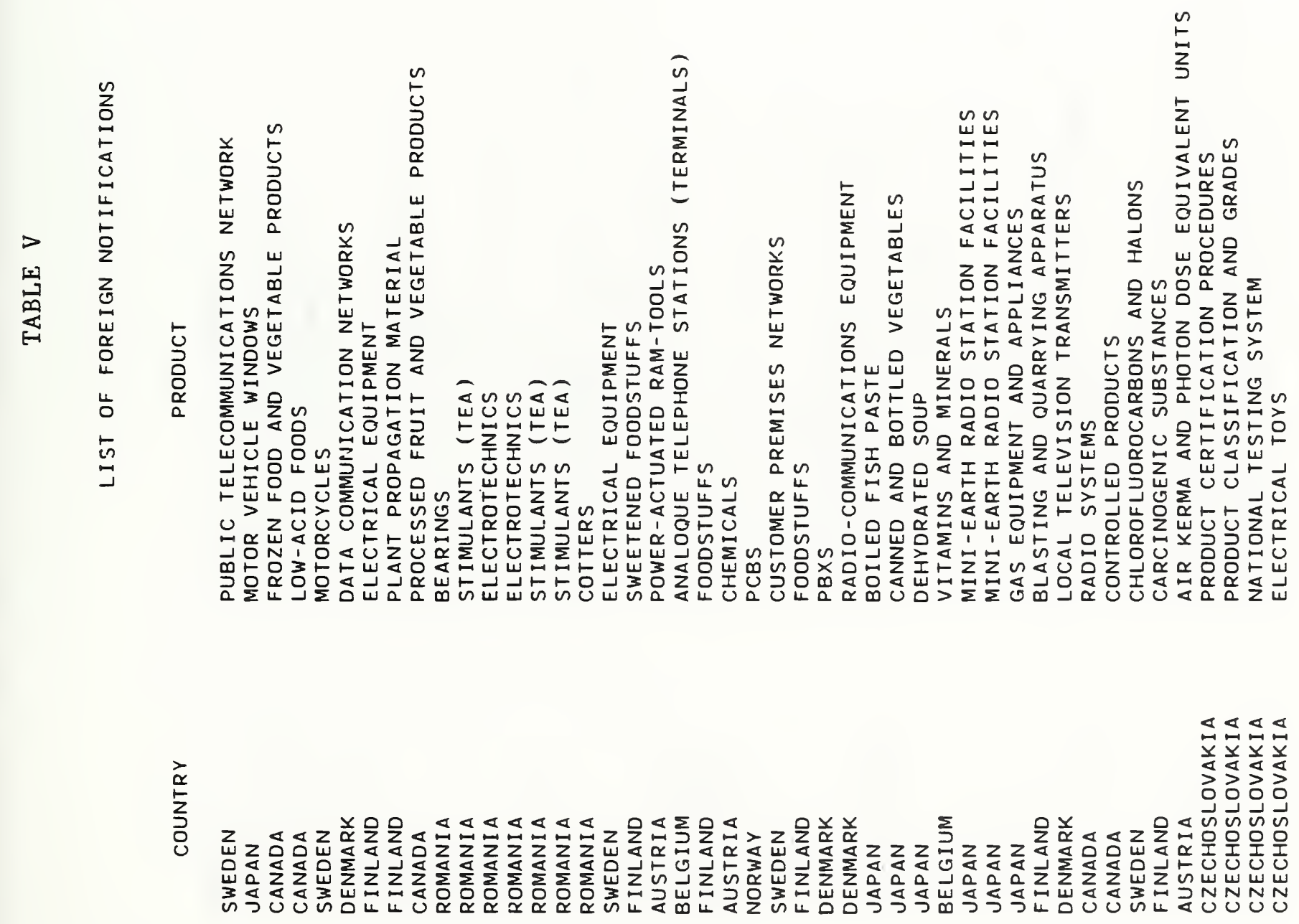

눈

-

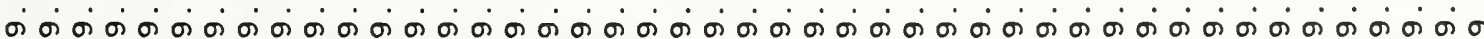

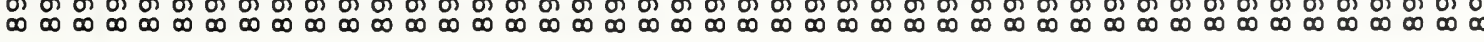




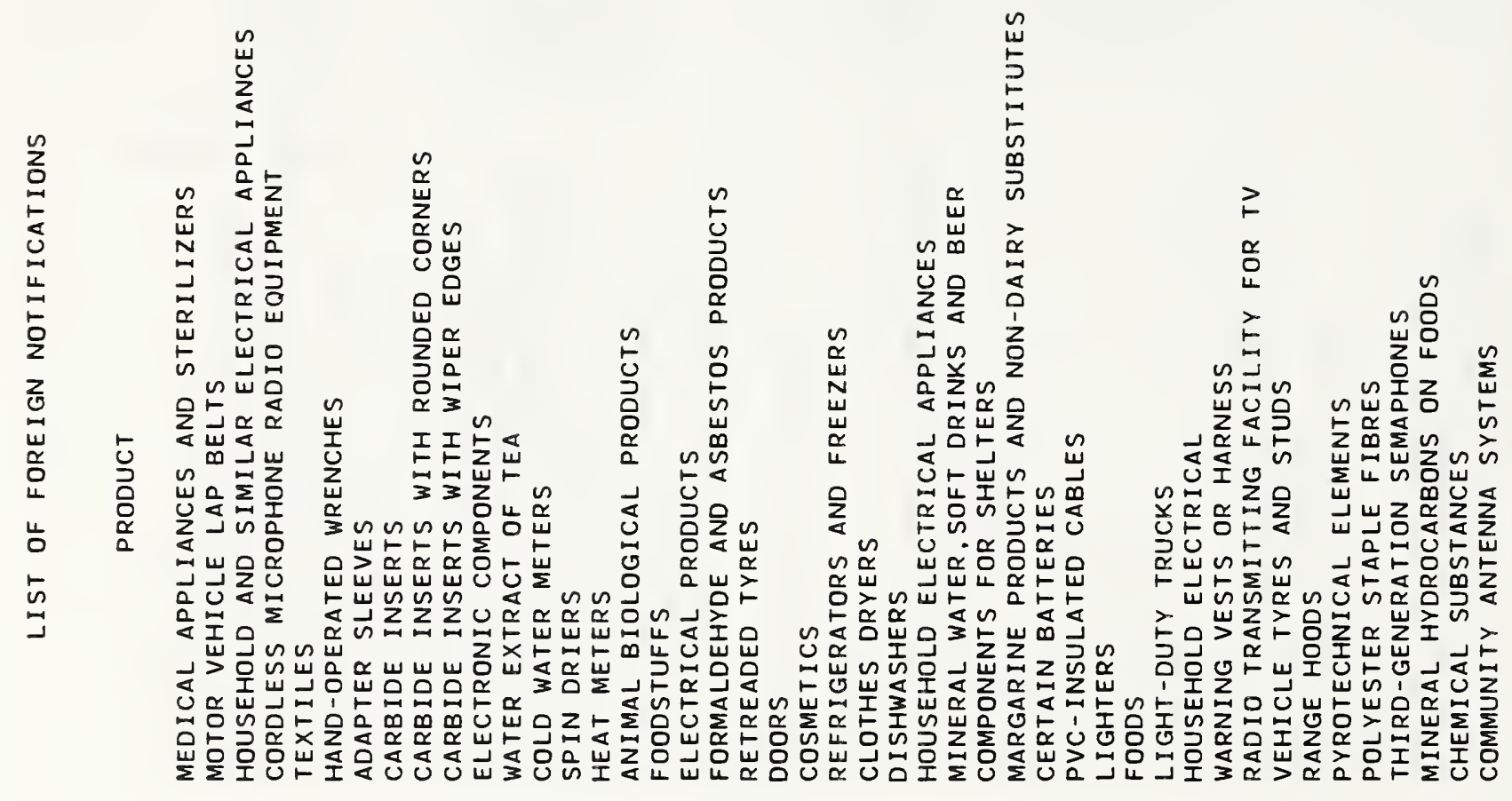

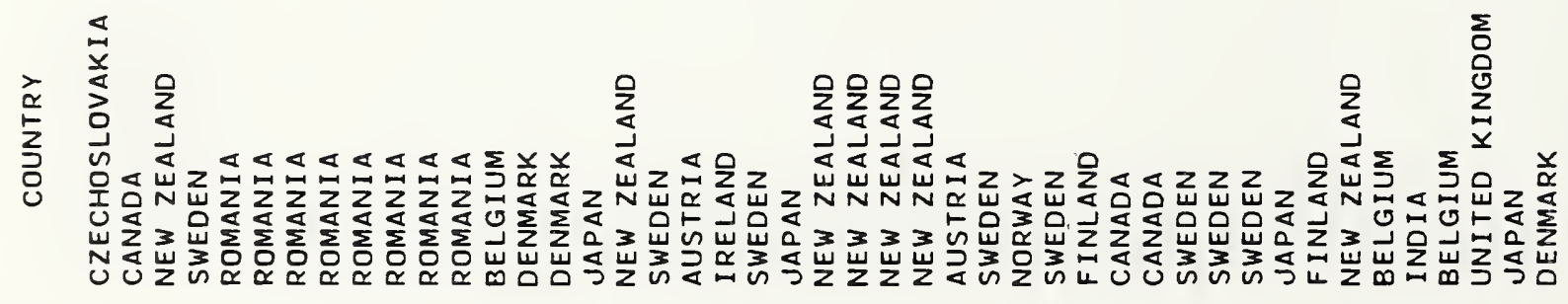

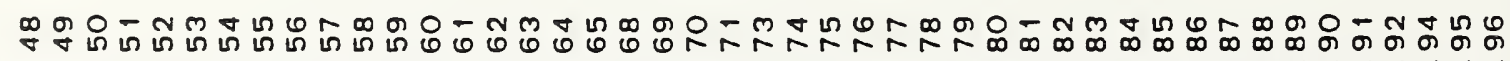

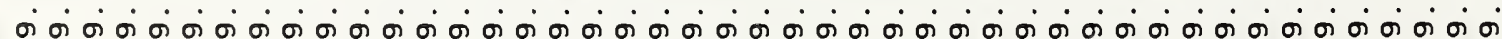
ఎ 
<smiles></smiles>

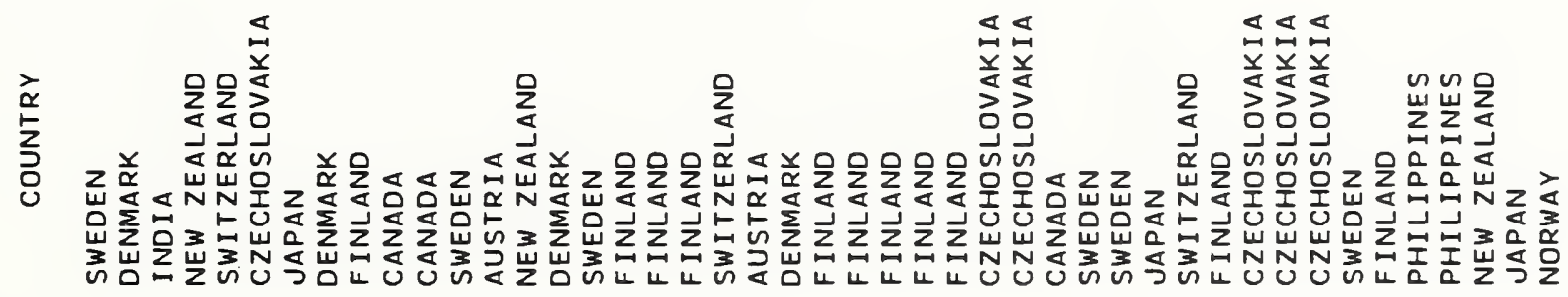

ผ็

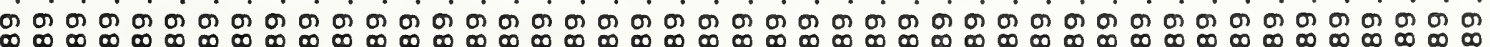

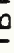




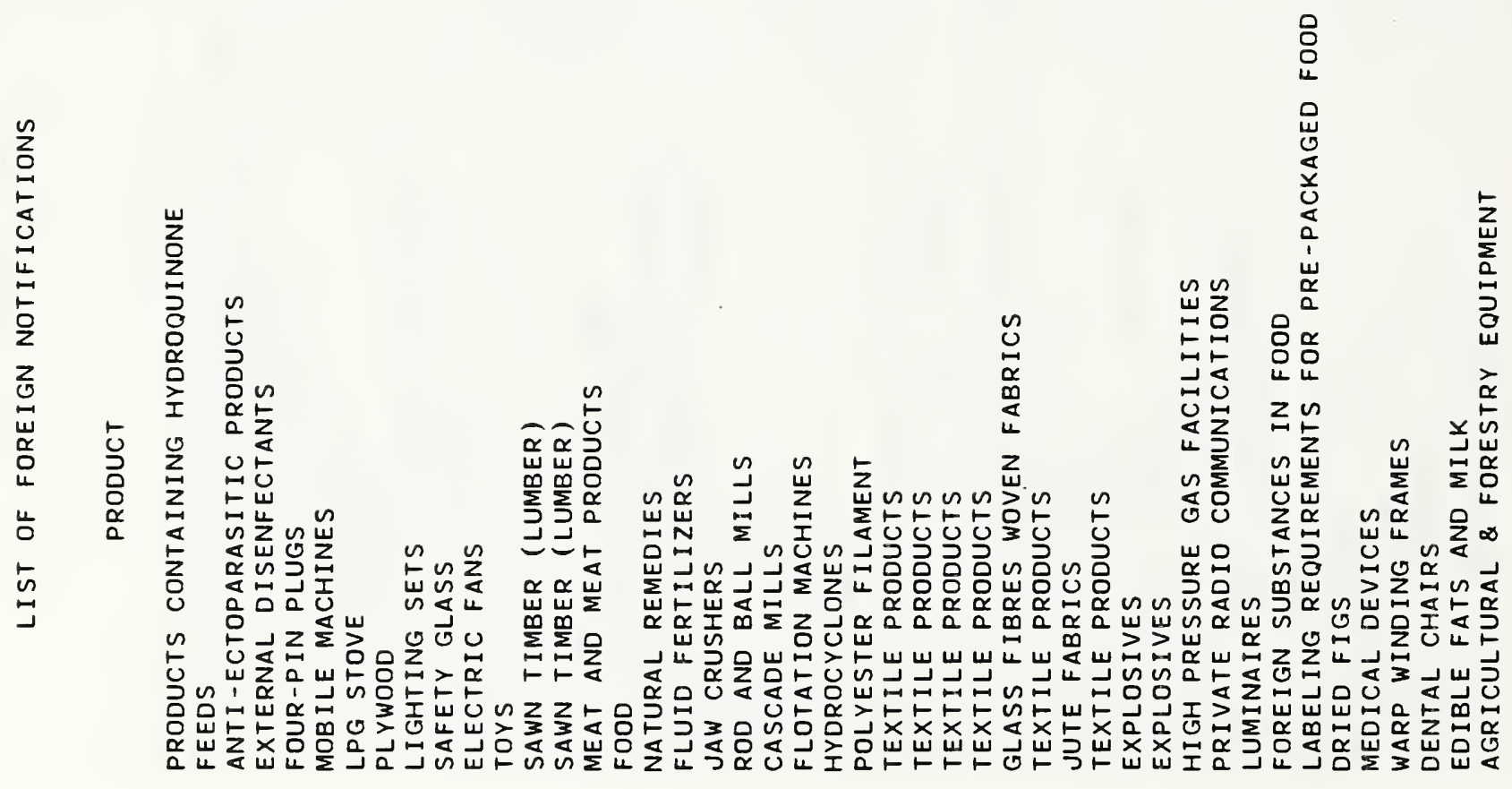

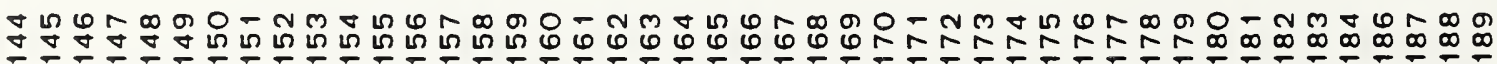

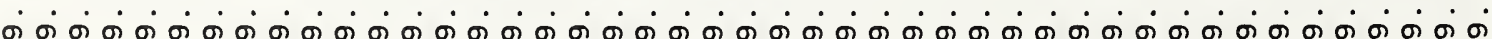

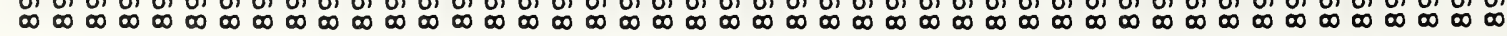



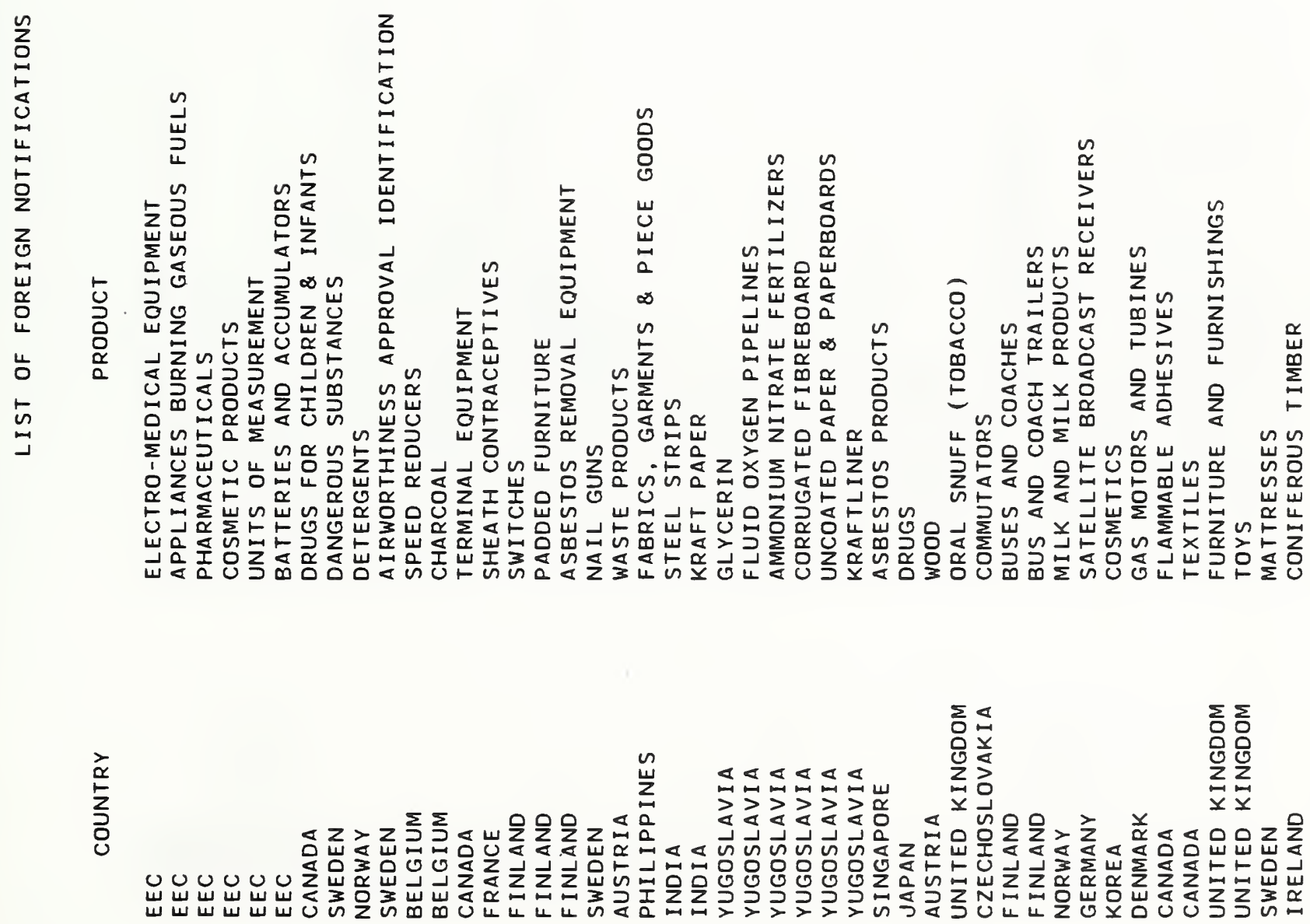
눈

-

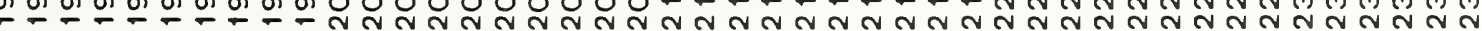

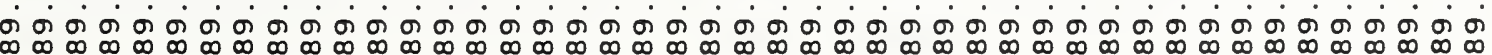




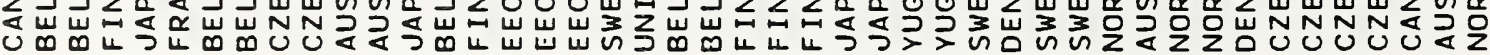

oromo-nm

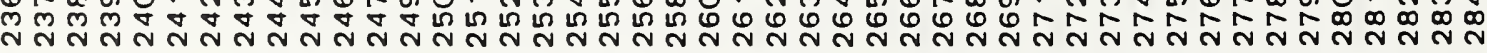

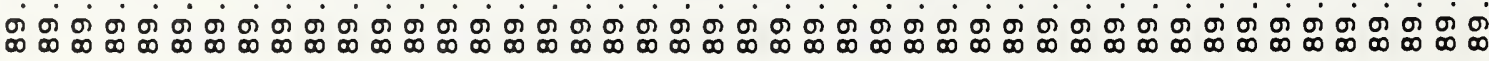



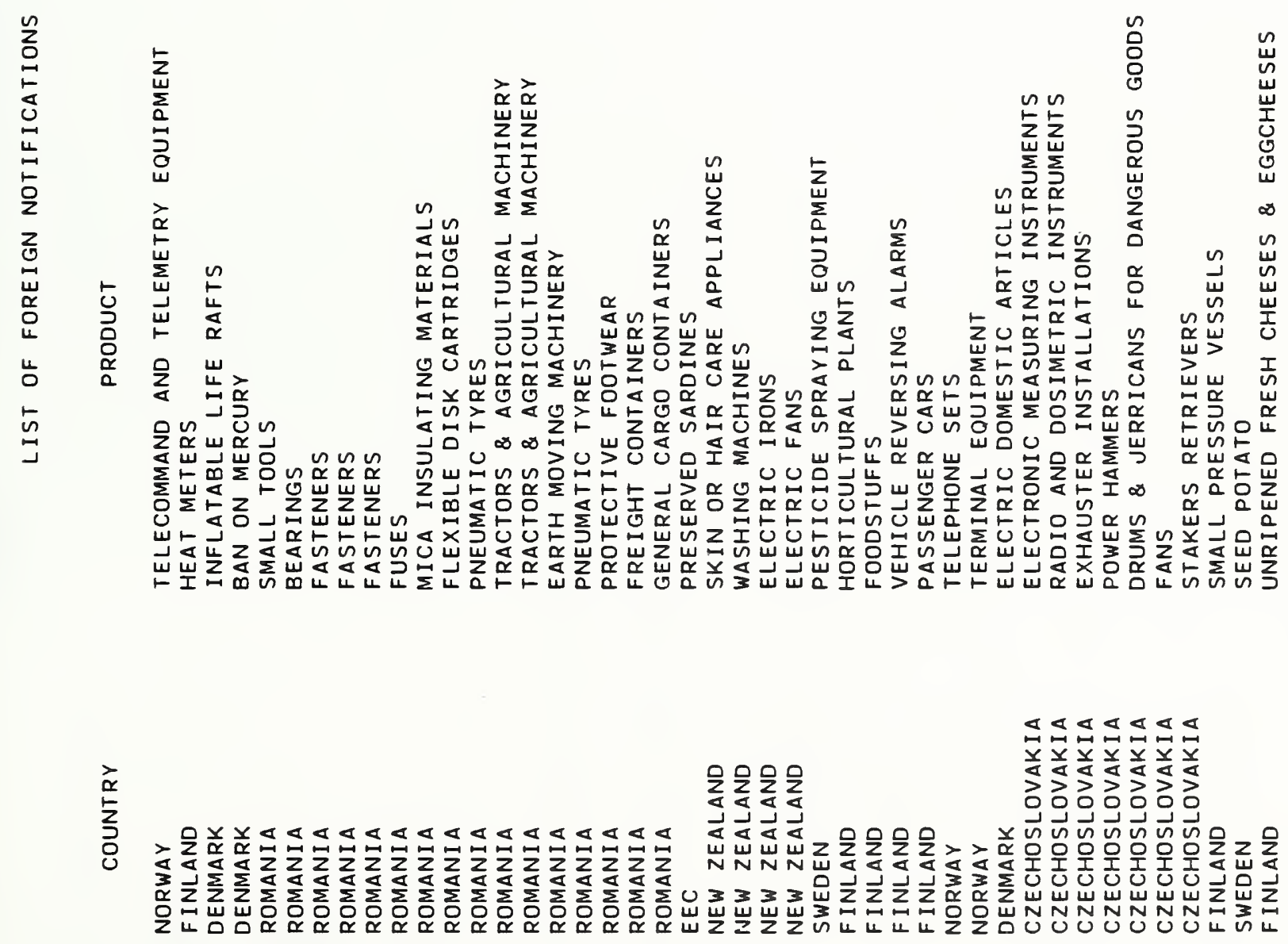

กำ 뚠

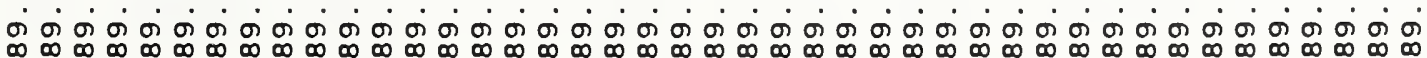


$\begin{array}{l:ll}2 & & \\ z & 0 \\ 己 & 0 & 0 \\ 0 & 1 & \infty\end{array}$

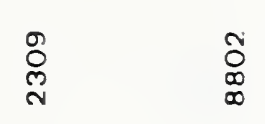

-

$\stackrel{\infty}{\infty}$

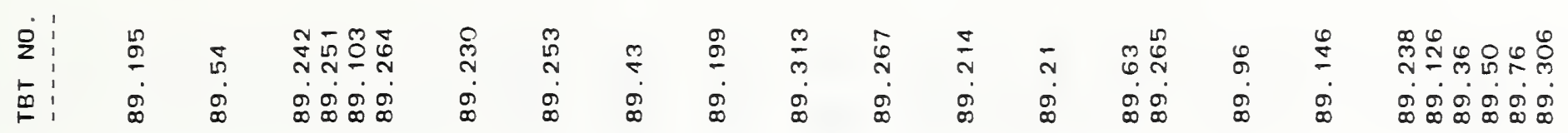

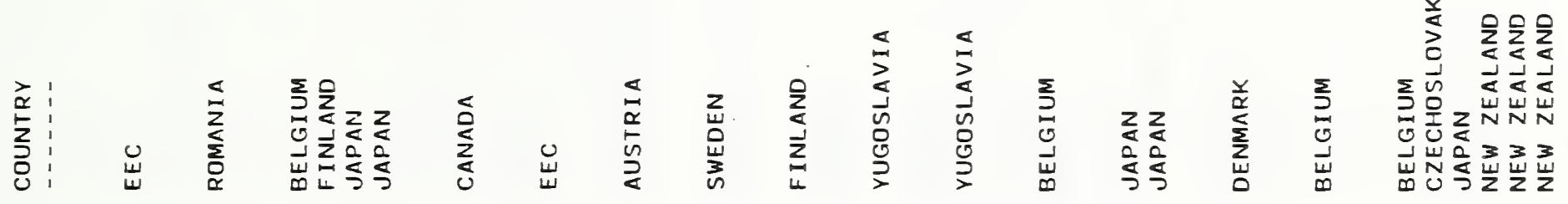

:

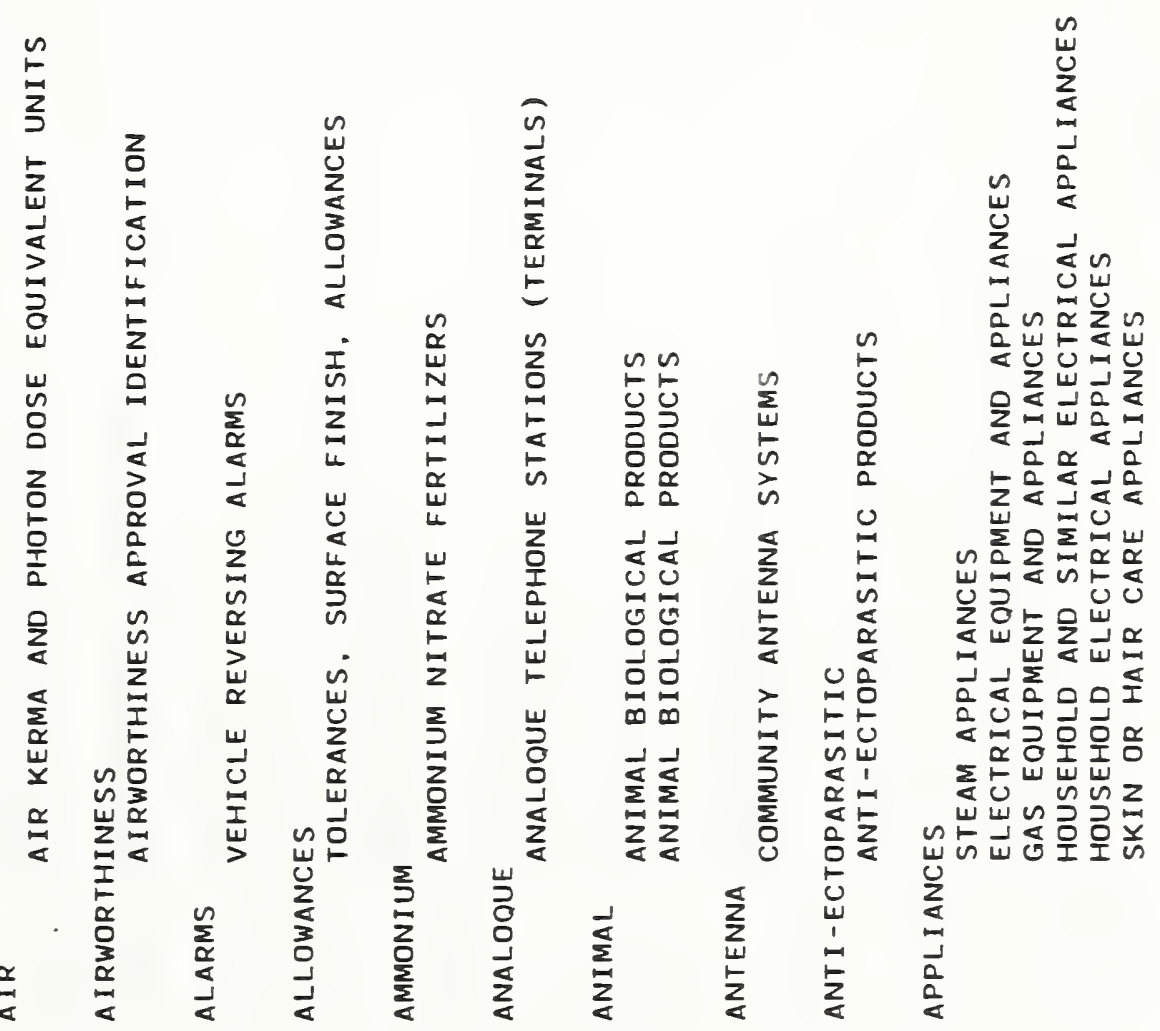


3
$\dot{s}$
$z$
0

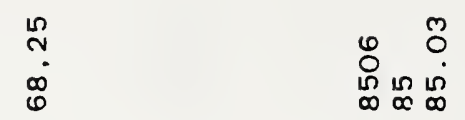

O্ণ

$\stackrel{8}{g}$

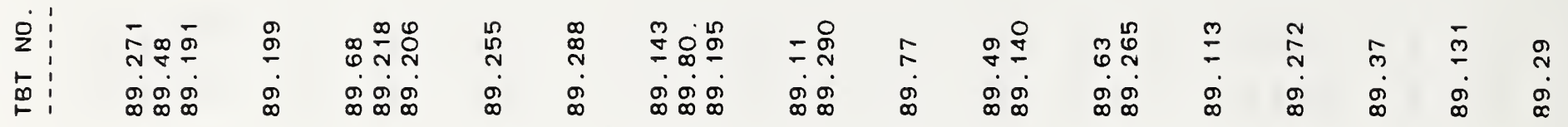

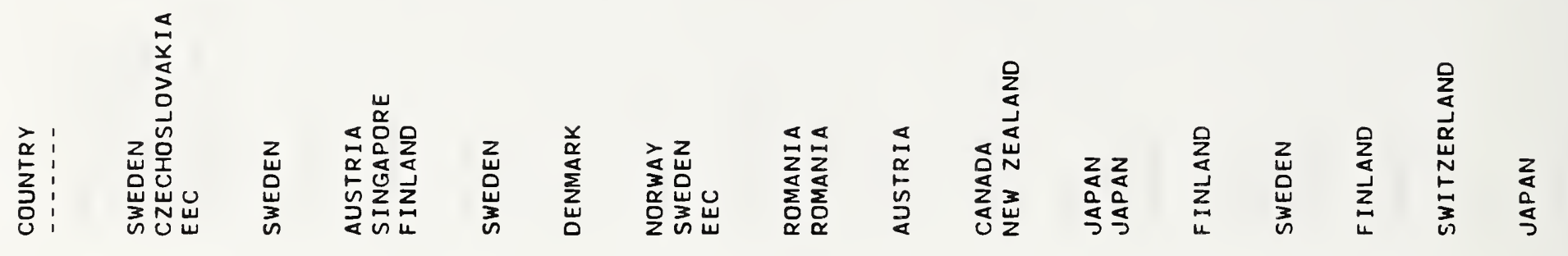

\begin{tabular}{l:c}
$\mathfrak{o}:$ \\
\hdashline \\
\hdashline \\
\hdashline \\
\hdashline
\end{tabular}
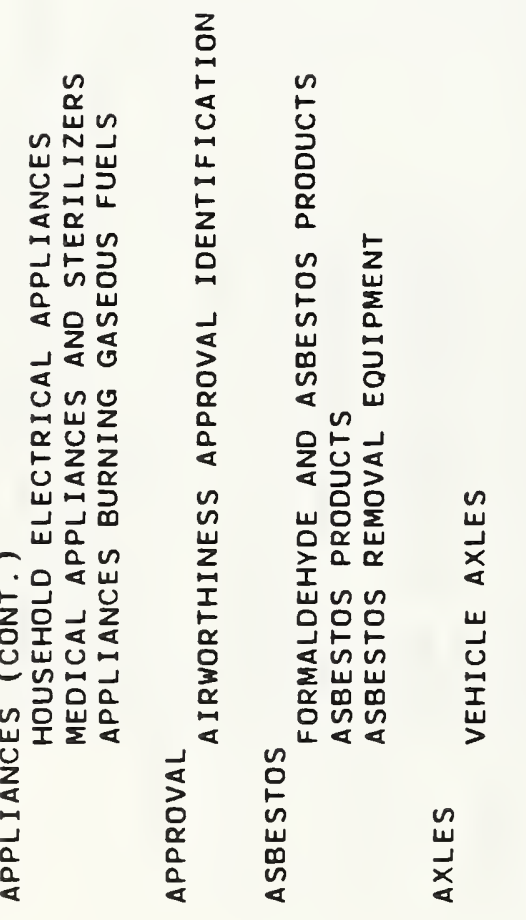

告

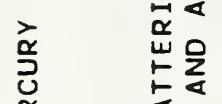

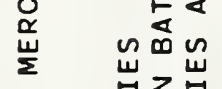

z 品察

ㄲ్ㅇ

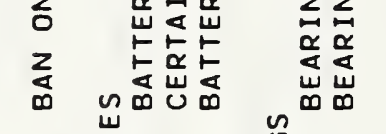

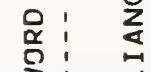

等:

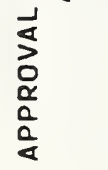

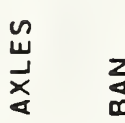

z

$\sum_{\substack{\infty \\ 0}}^{\underbrace{\infty}_{0}}$

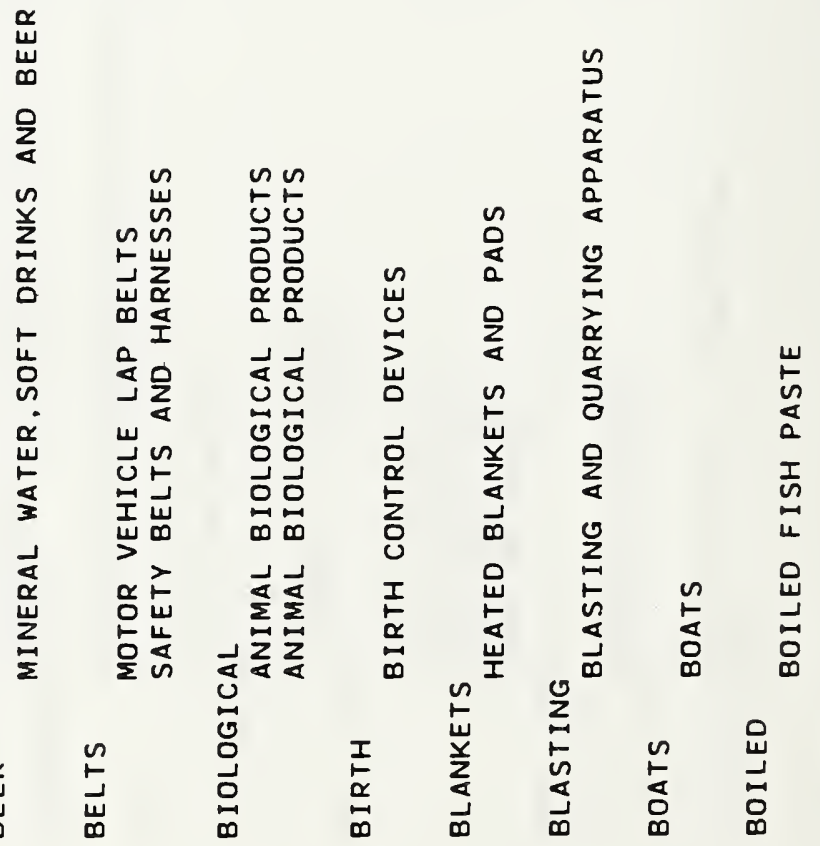




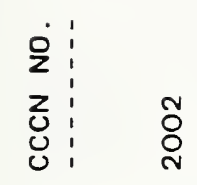

$\begin{array}{lllll}\stackrel{n}{n} & \stackrel{0}{0} & & \stackrel{n}{\infty} \\ \stackrel{\infty}{\infty} & \infty & \infty & \sigma \dot{\sigma}\end{array}$

芶

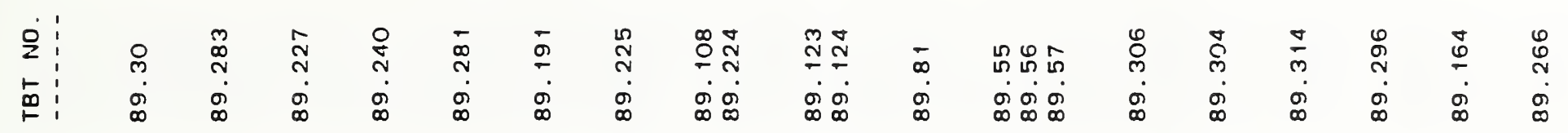

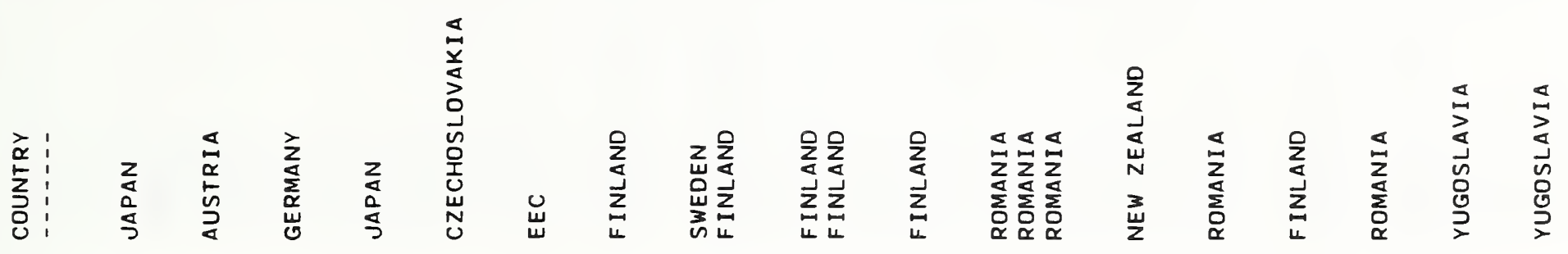

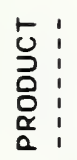

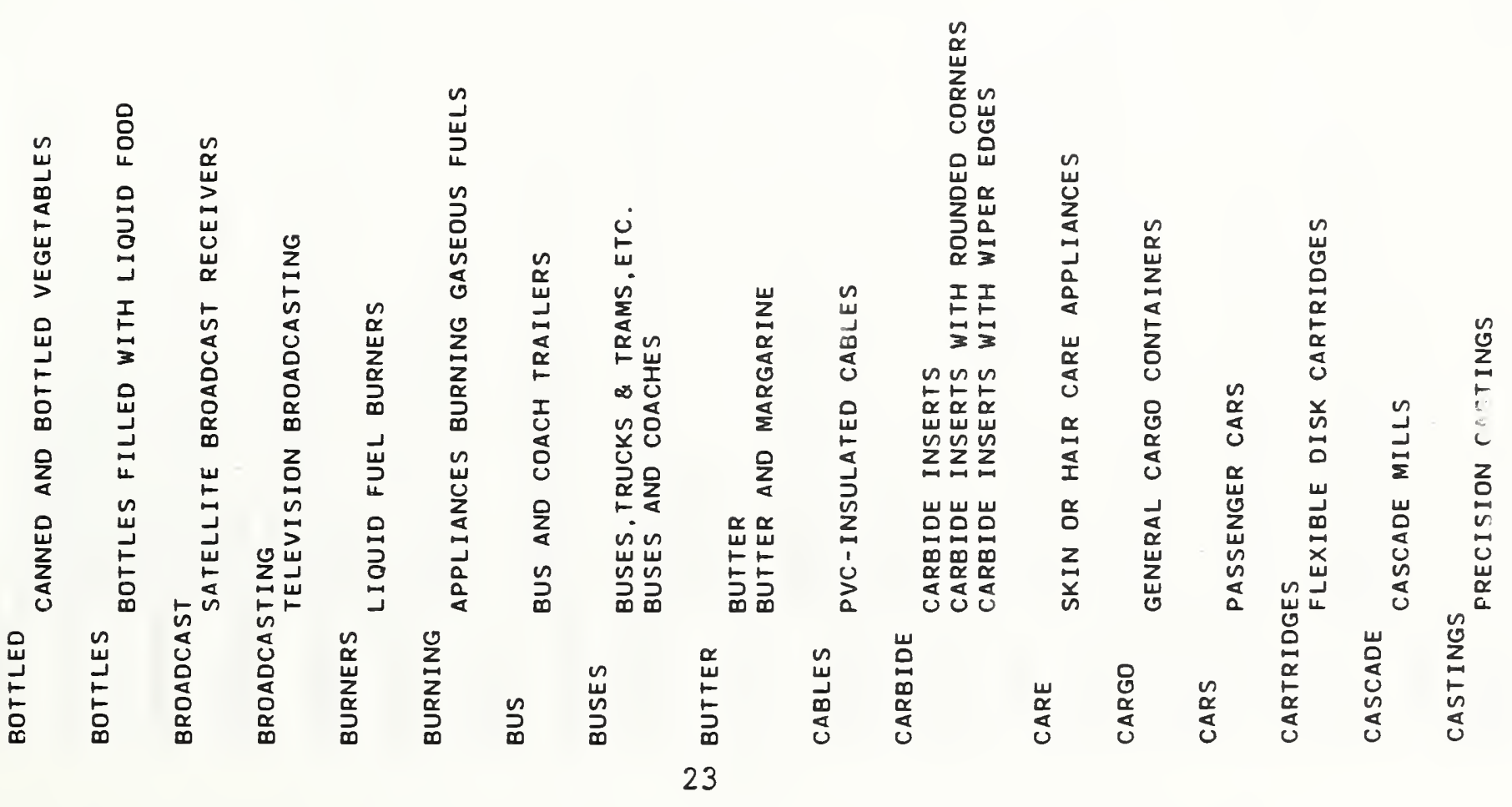


:

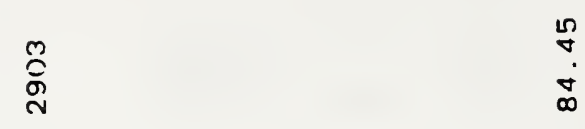

5

$\infty_{\infty}^{\infty}$

i

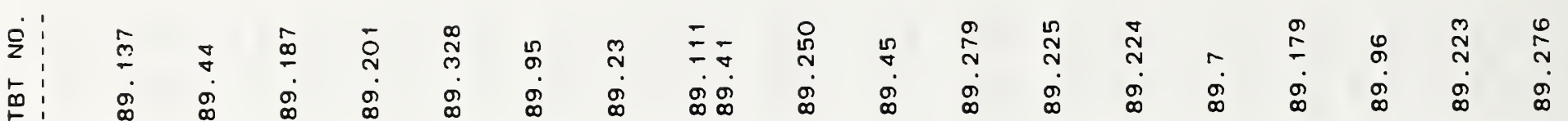

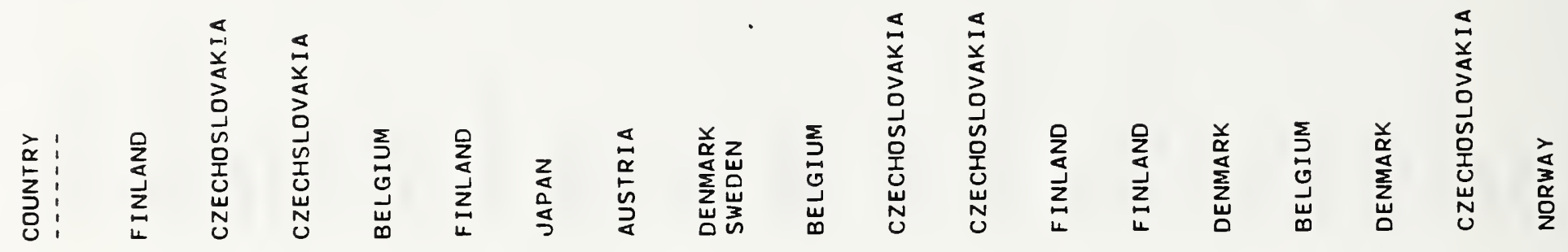

旁:

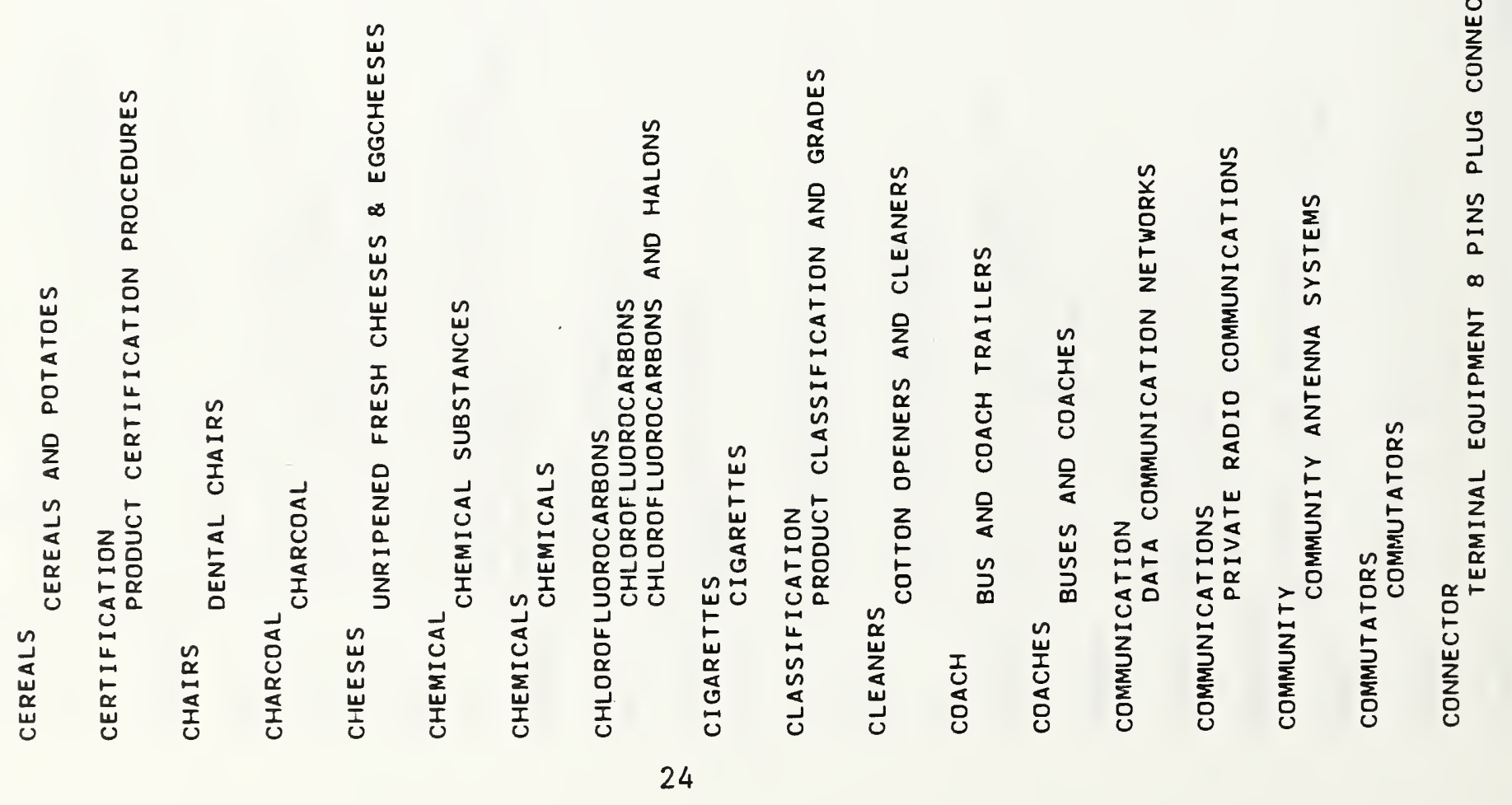




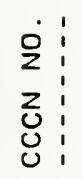

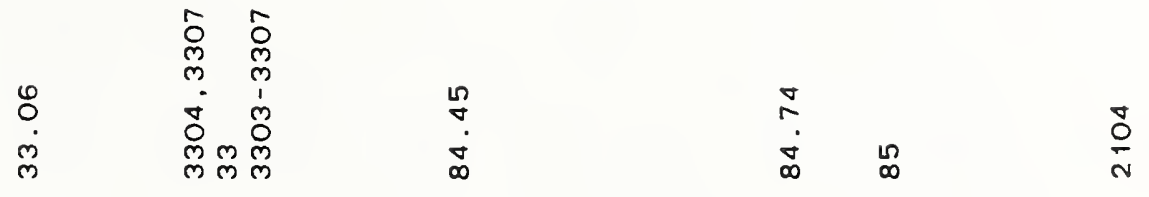

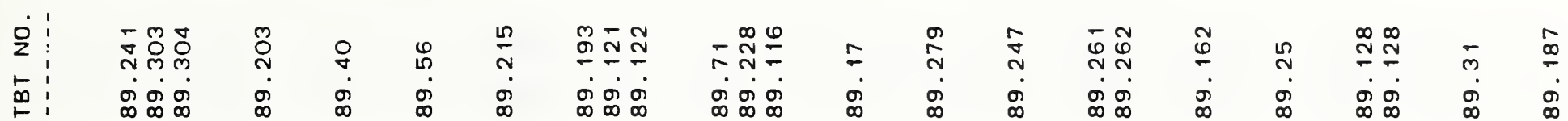

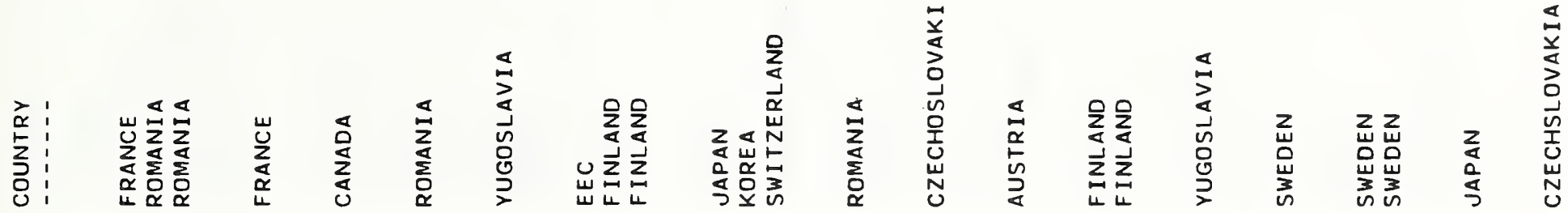

:

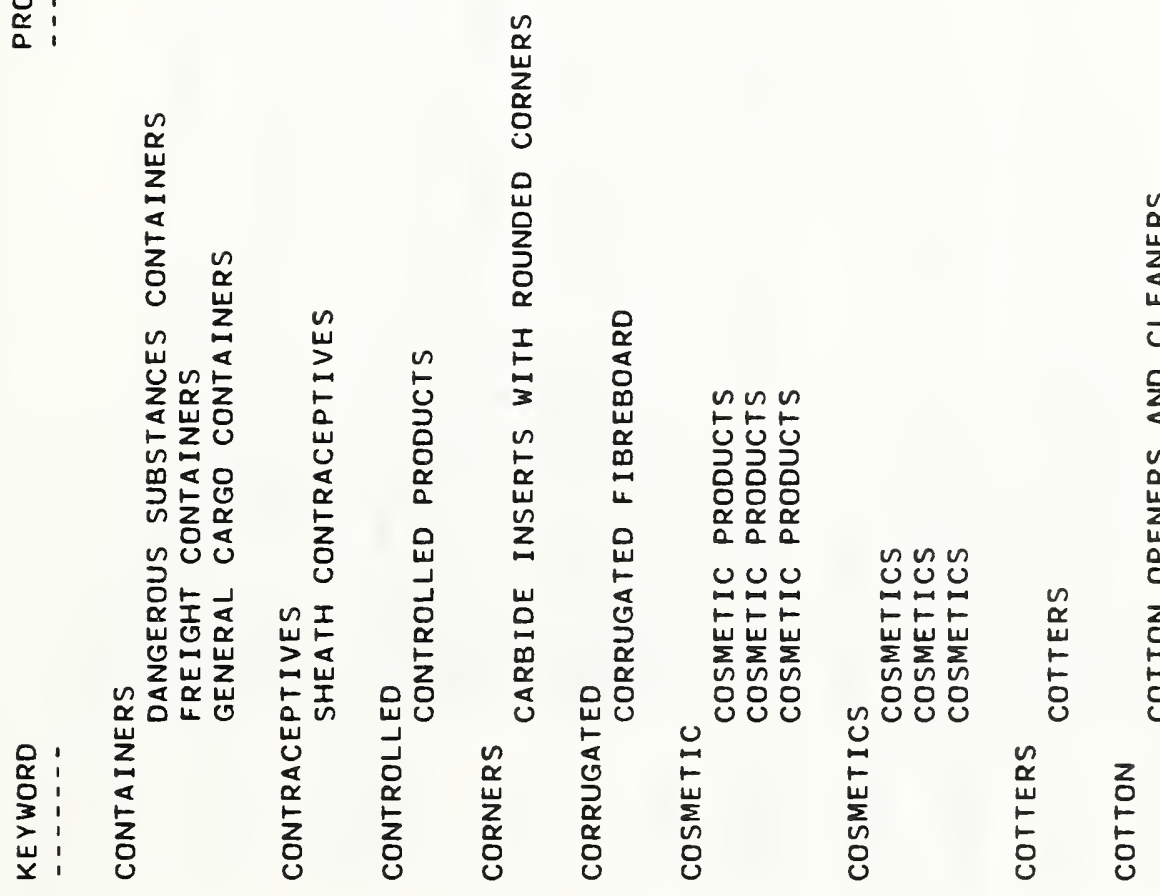


$\begin{array}{l:ll}0 & & \\ 2 & & - \\ z & 0 & 0\end{array}$

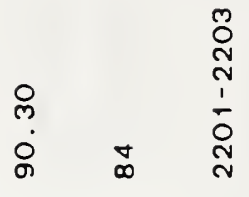

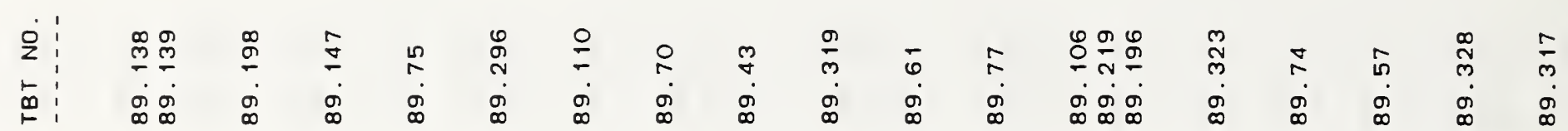

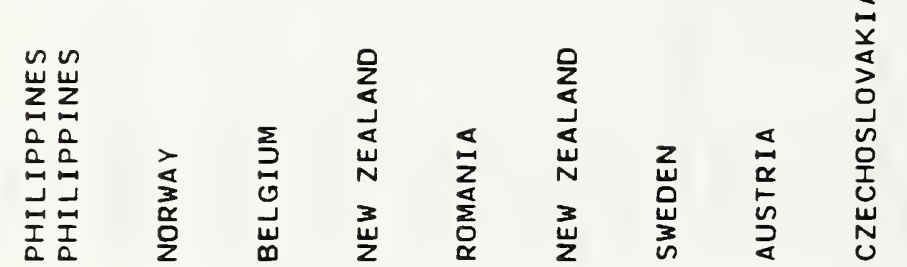

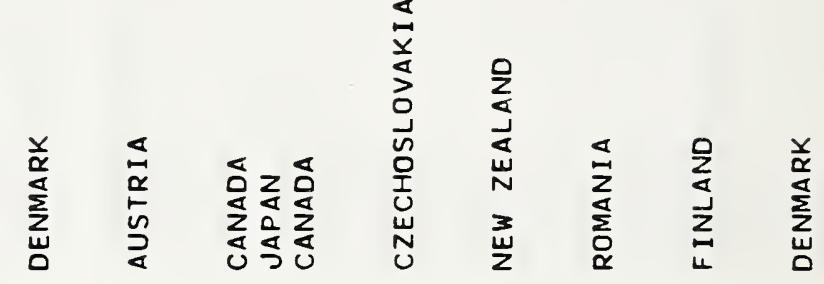

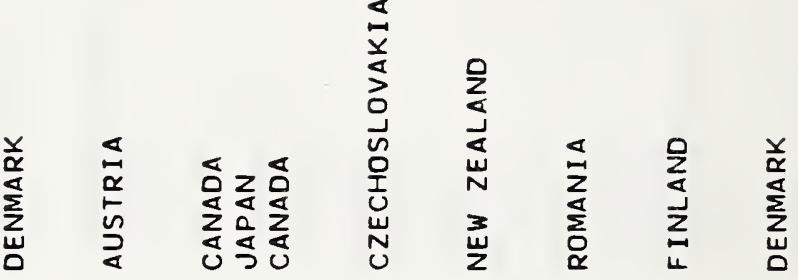

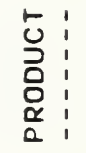

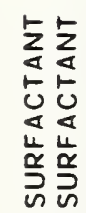

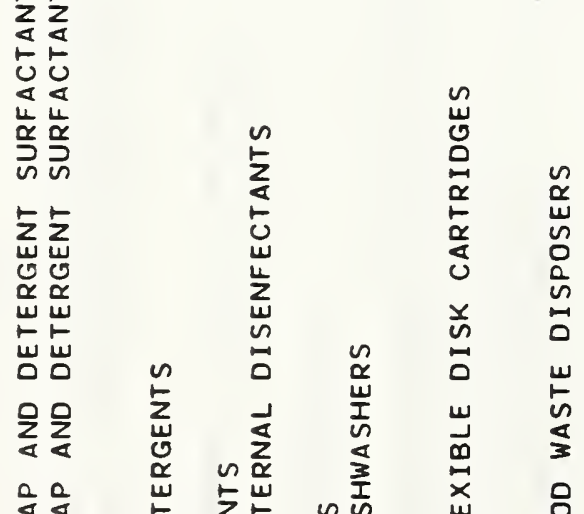

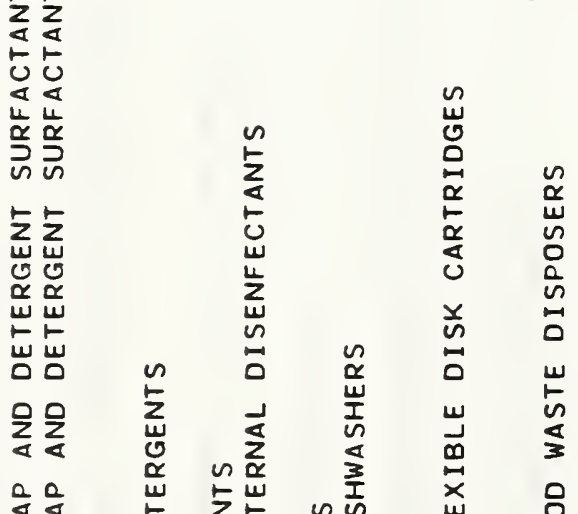

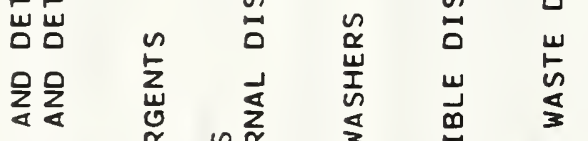

章

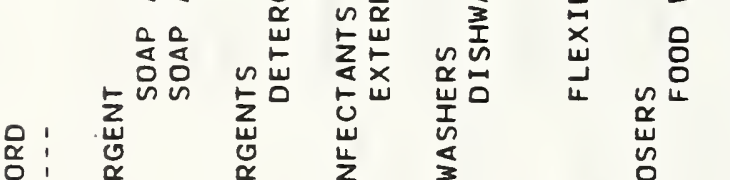

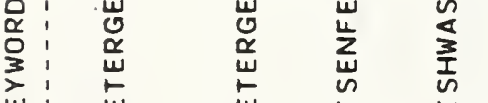

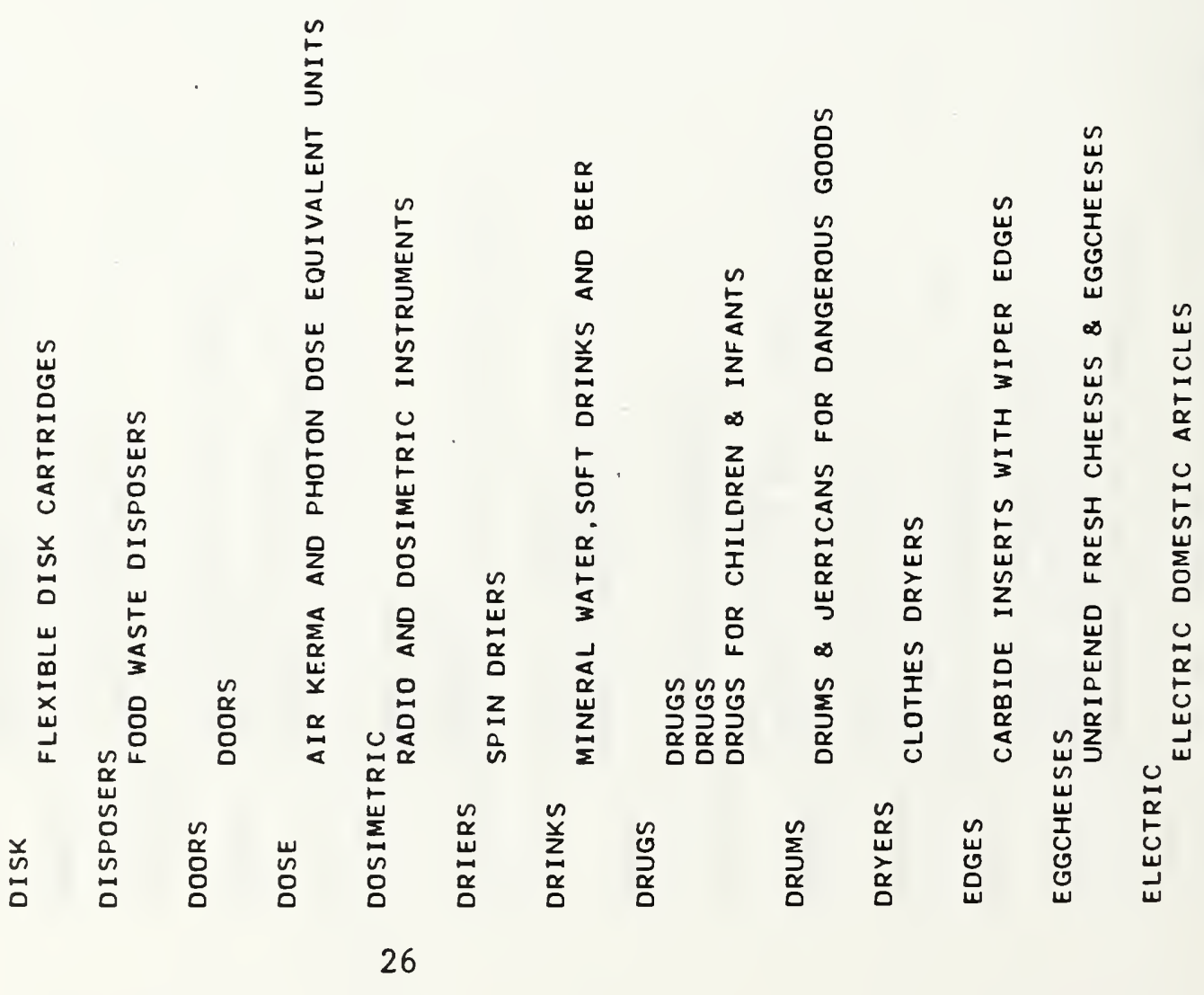


$\begin{array}{l:l}0 & \\ 2 & 0 \\ z & 0\end{array}$

우

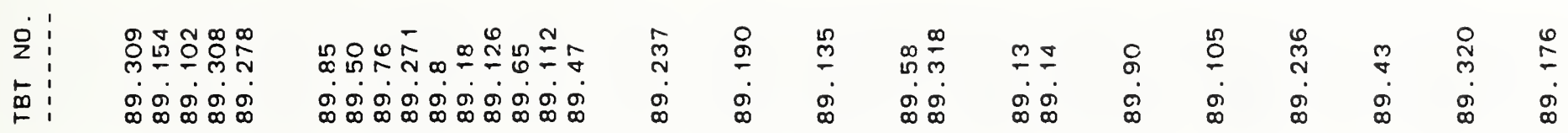

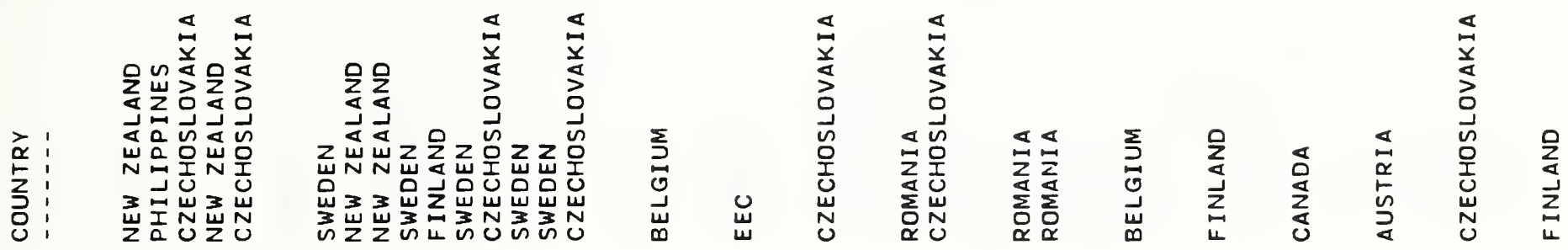

\begin{tabular}{c:c}
$\leftarrow$ \\
\hdashline \\
\hdashline \\
\hdashline \\
\hdashline
\end{tabular}$:$

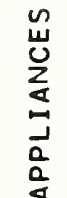

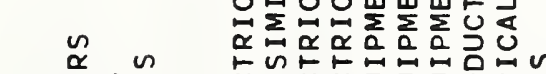

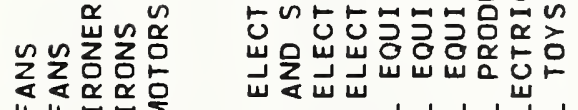

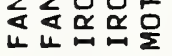

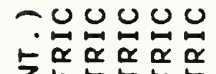

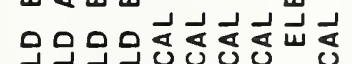

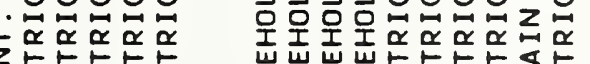

Un山

ل्य

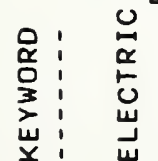

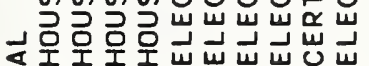

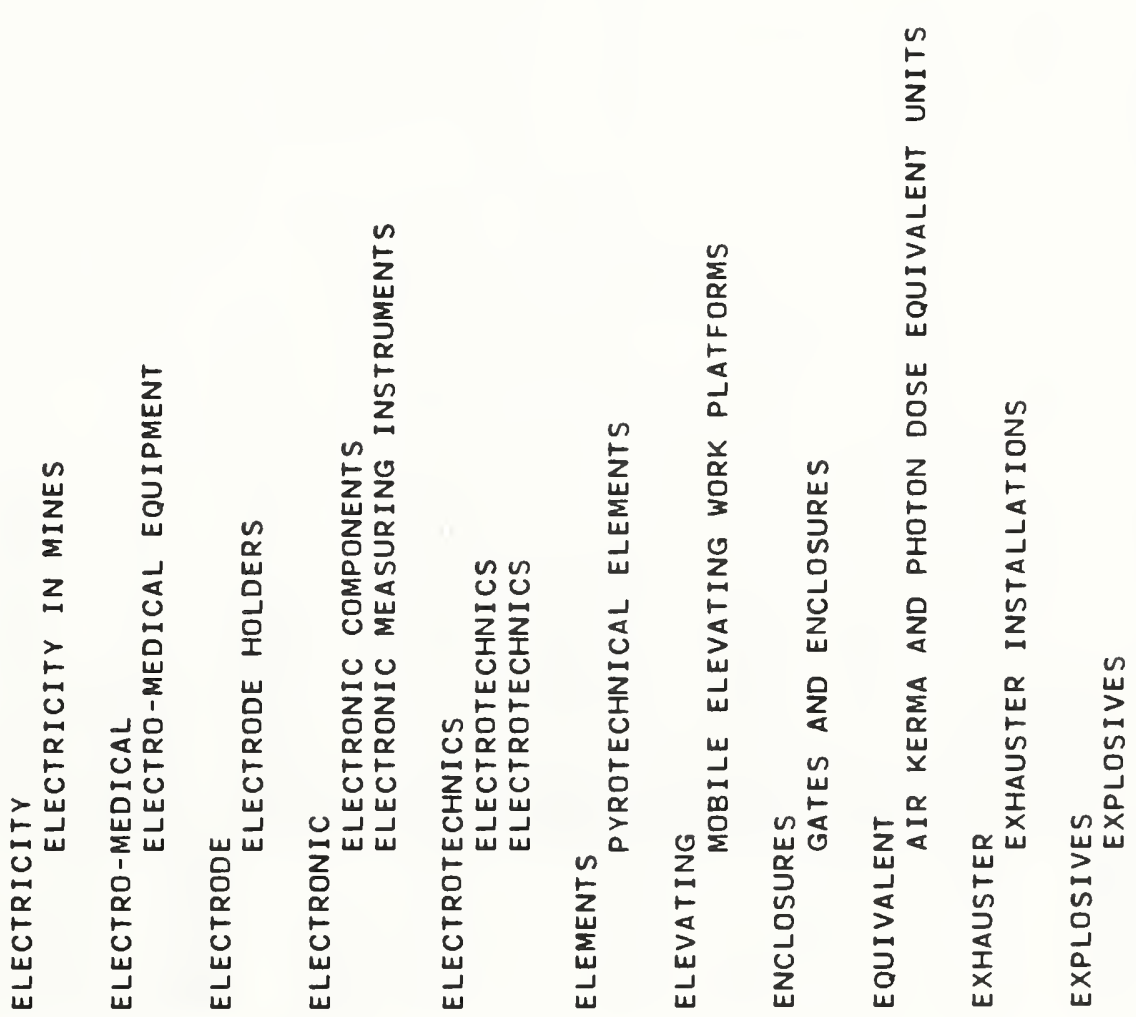


is

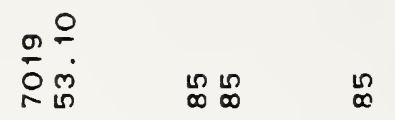

ํํㅇ ำ

लिं

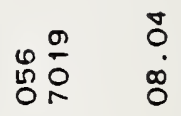

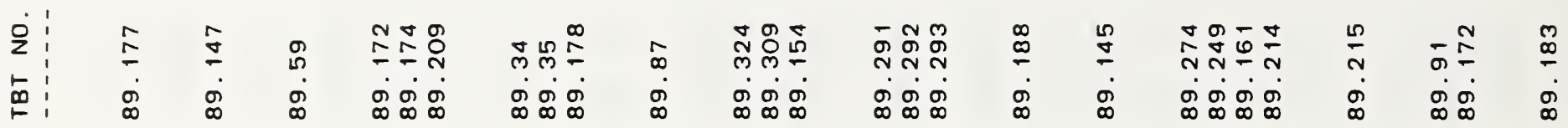

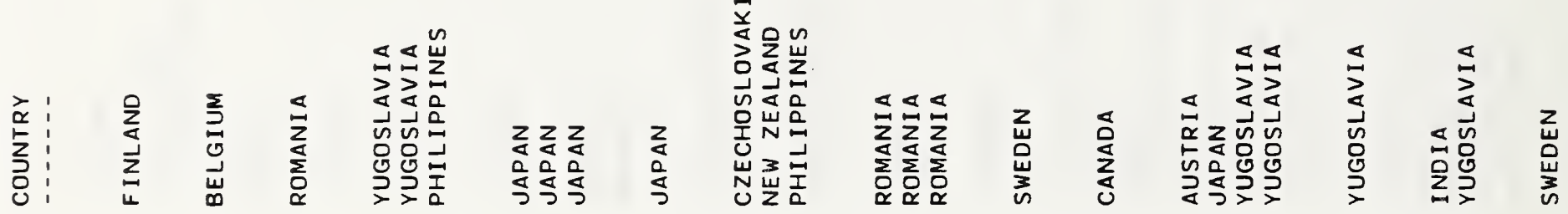

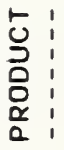

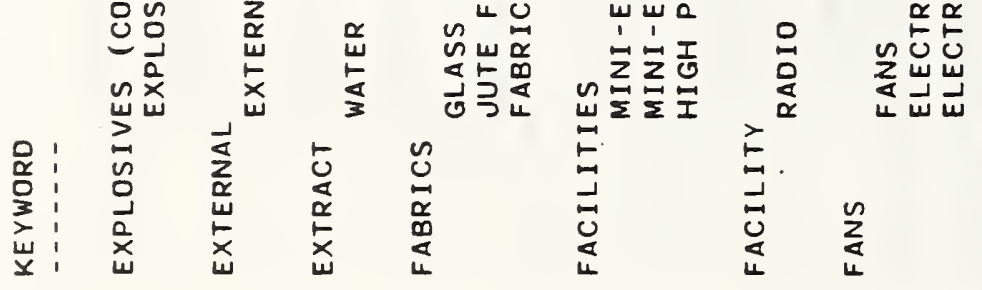
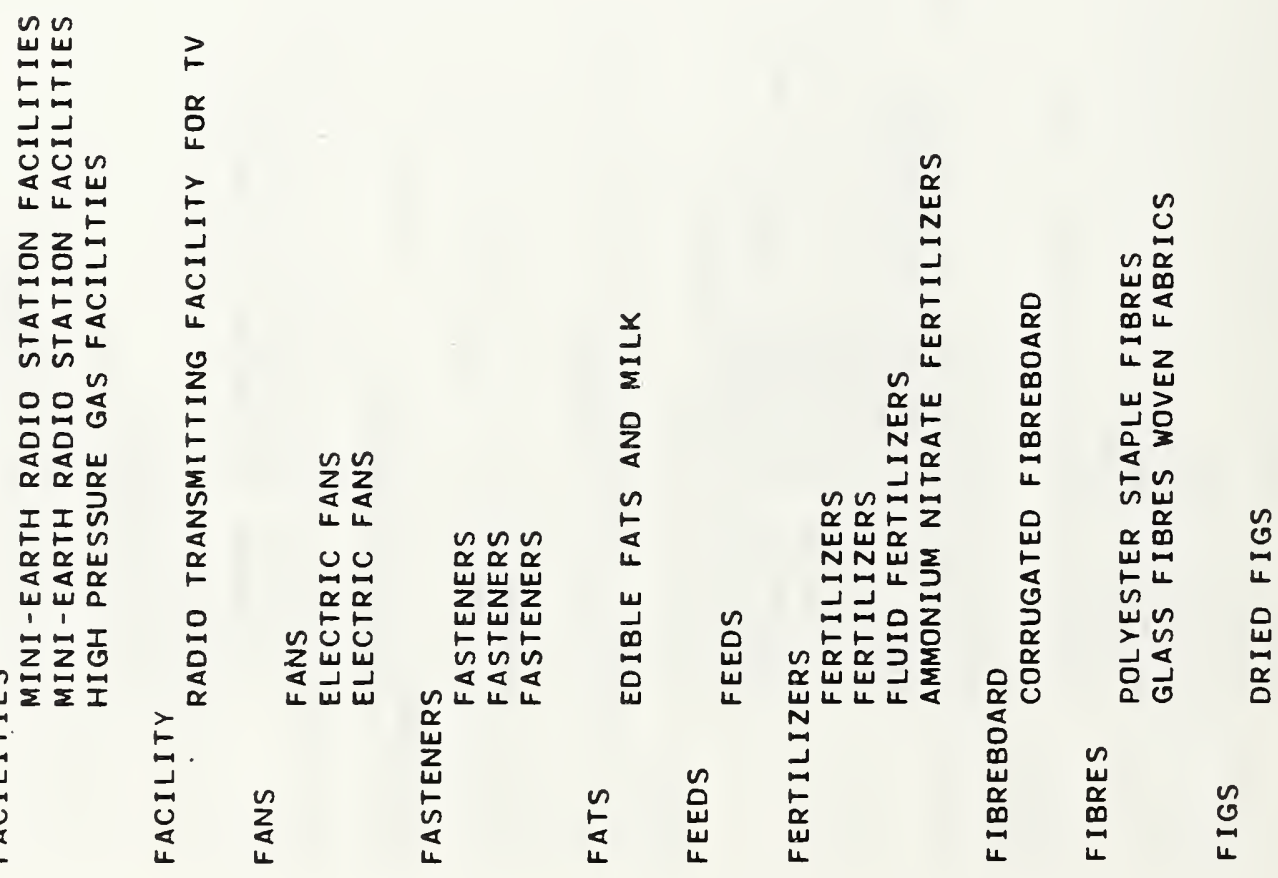


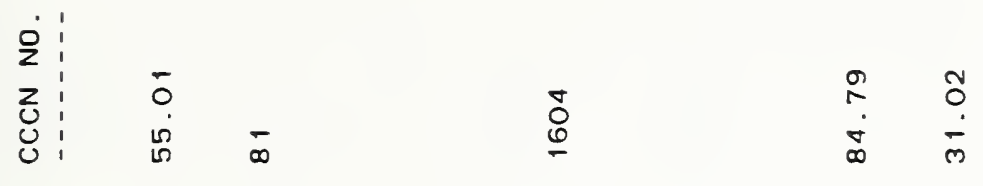

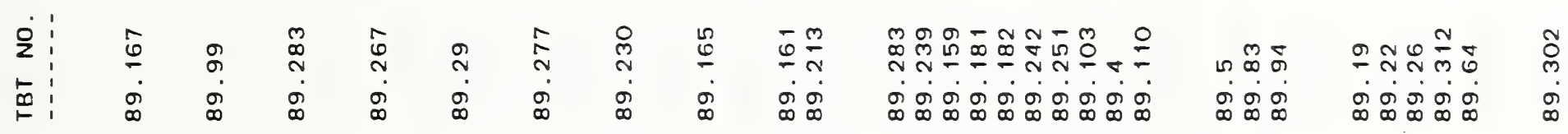

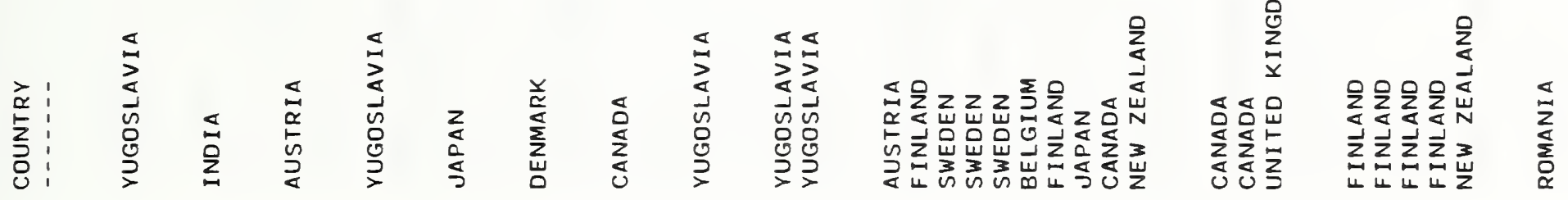

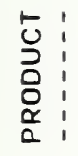

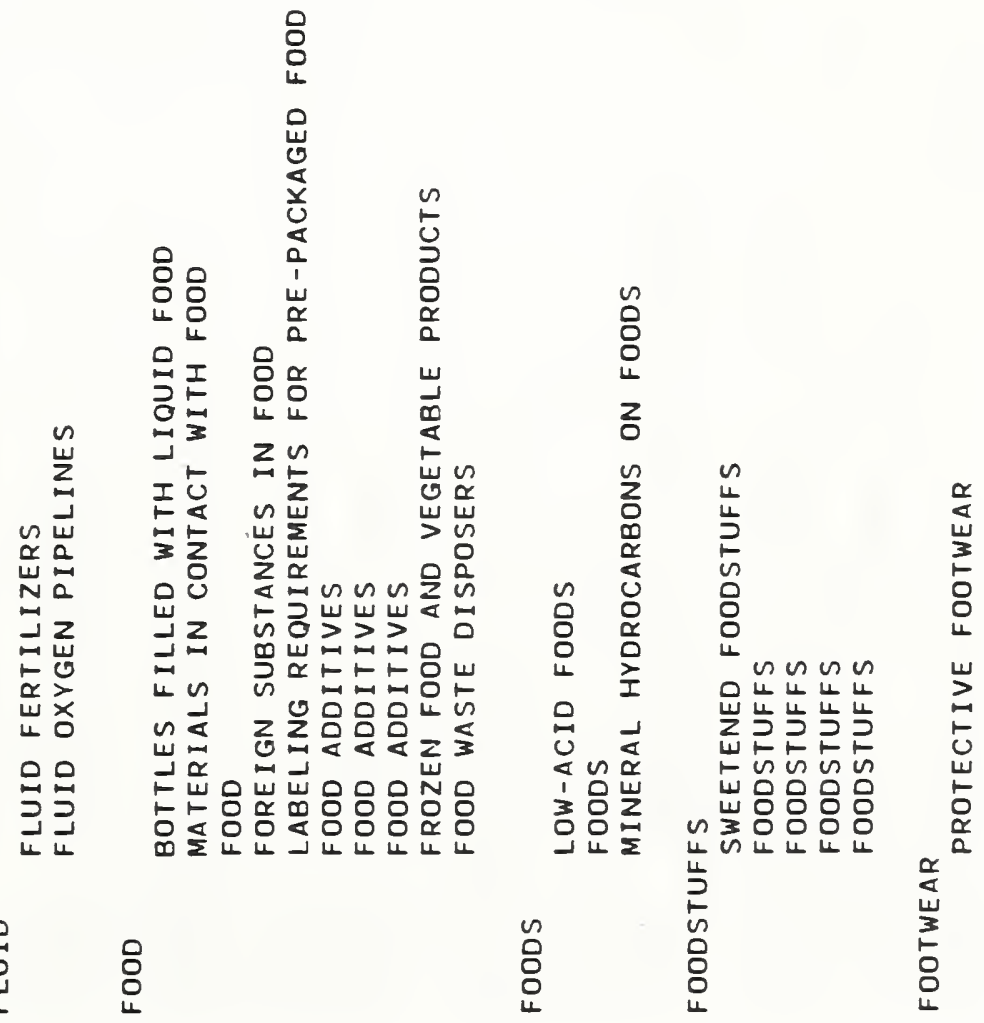




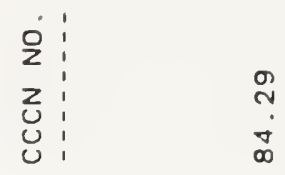

$\stackrel{\square}{\dot{5}}$

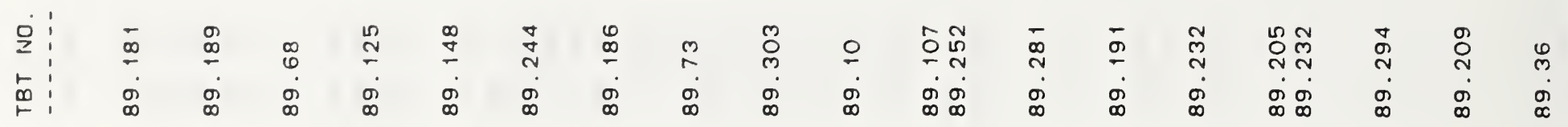

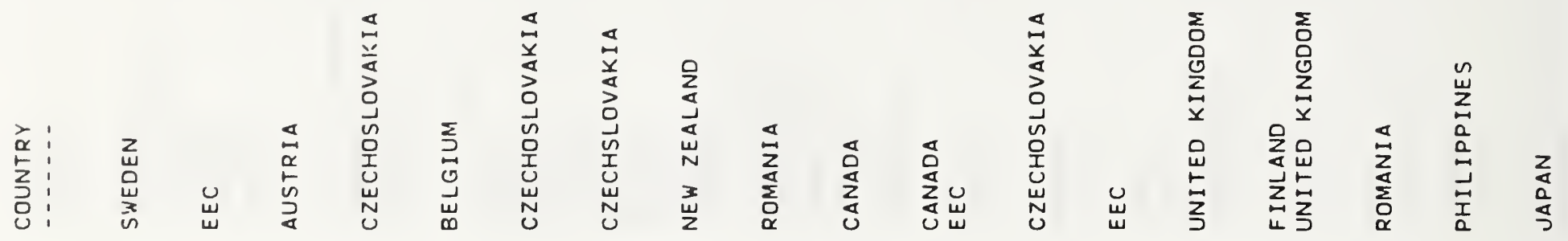

\begin{tabular}{l:c}
$\leftarrow$ \\
\hdashline \\
\hdashline
\end{tabular}$:$

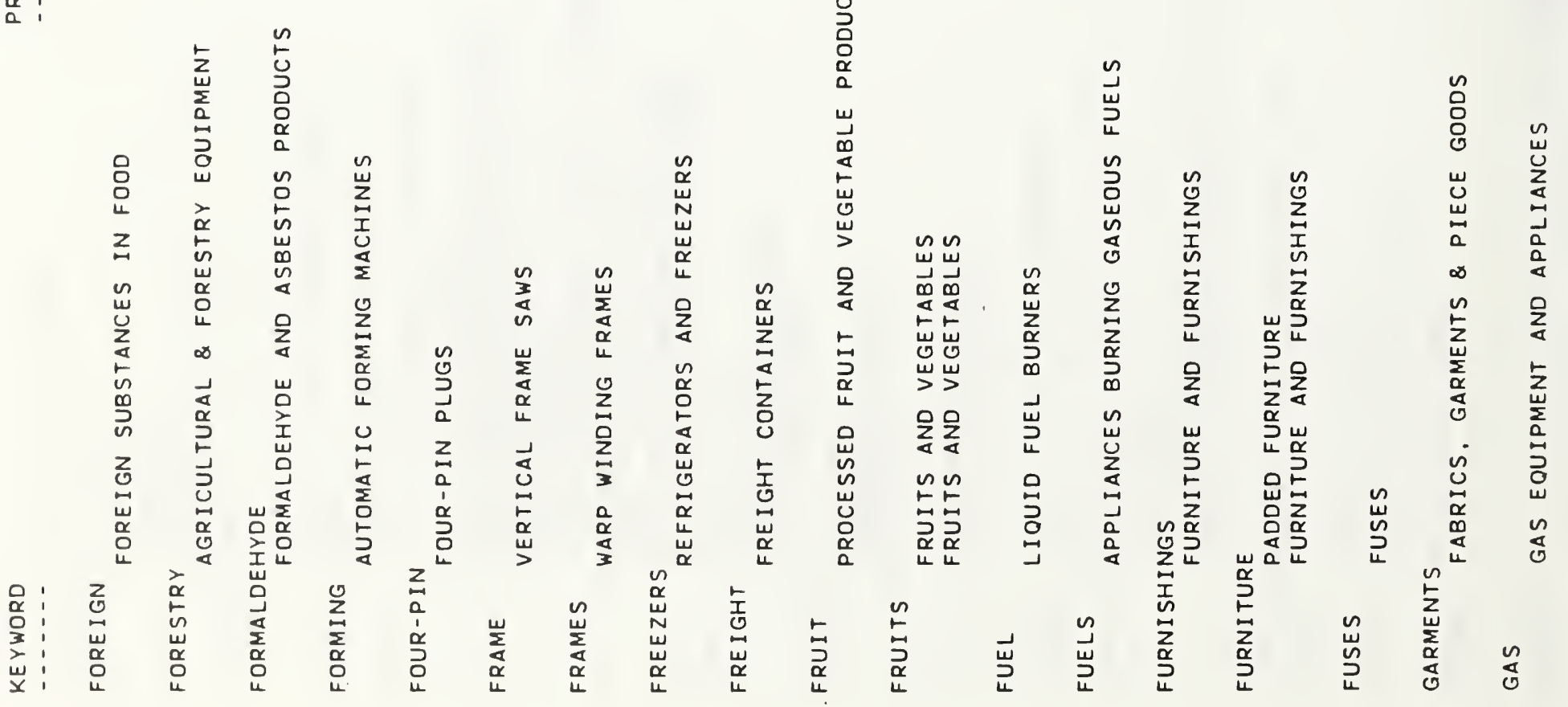




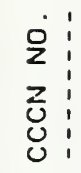

$\stackrel{\circ}{\stackrel{\circ}{\circ}}$

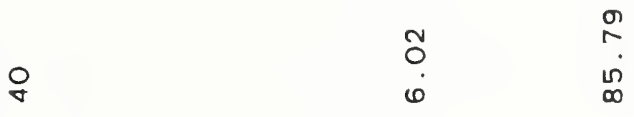

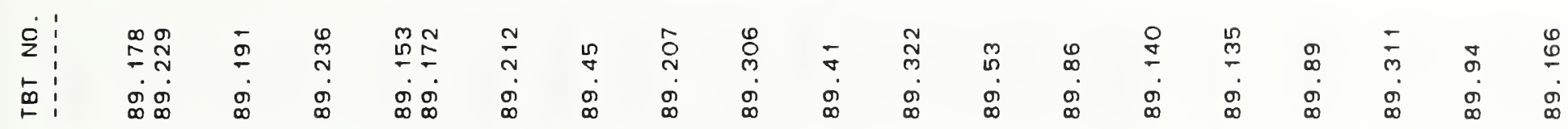

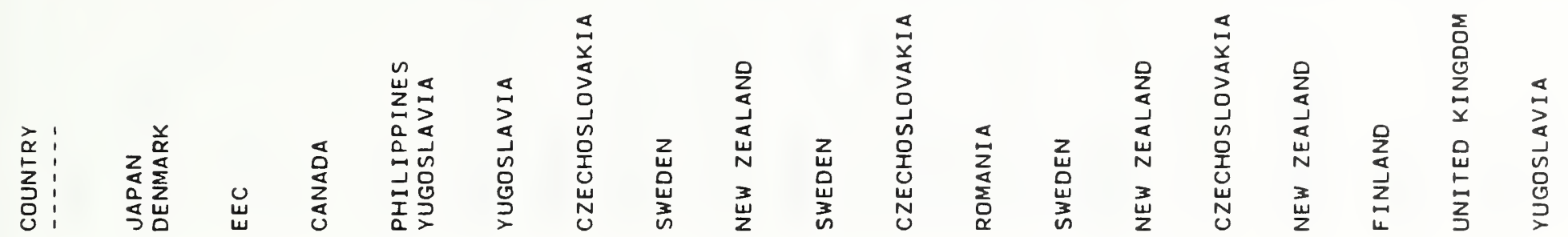

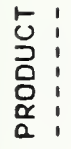

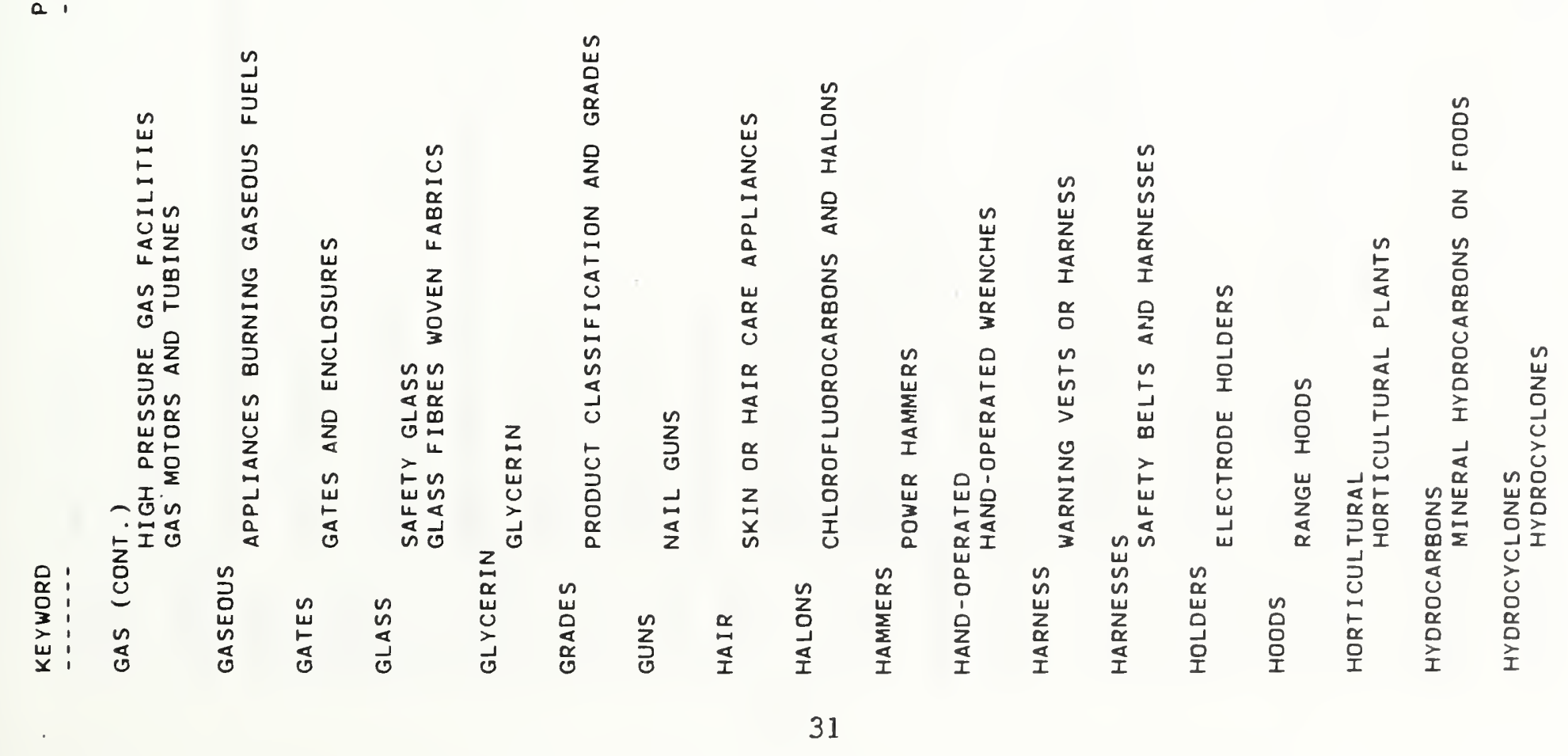


定:

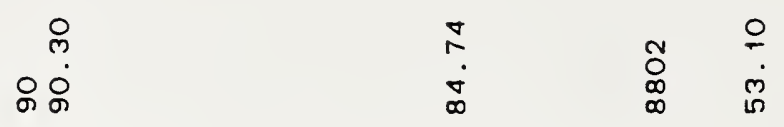

$\overline{0}$
$\infty$
$\dot{\sigma}$

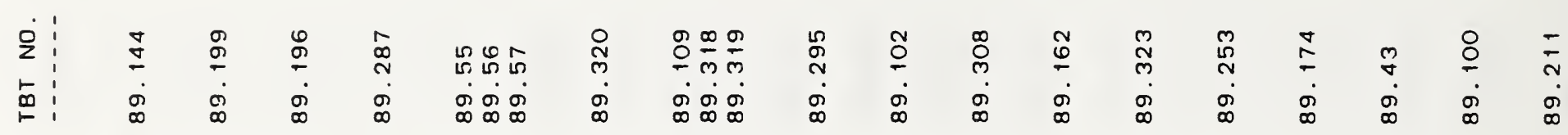

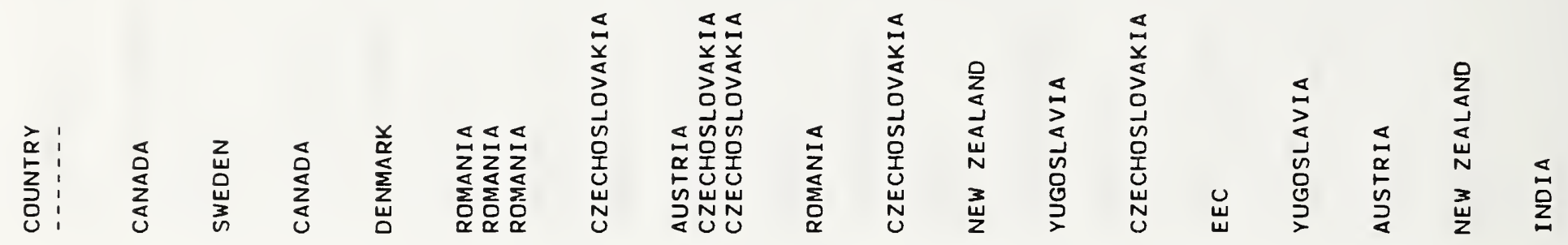

:

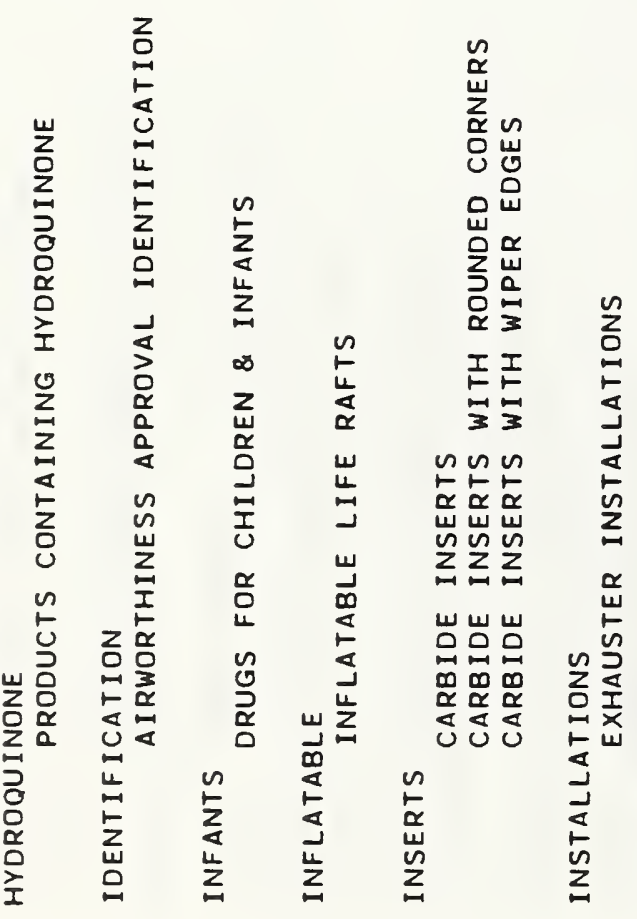

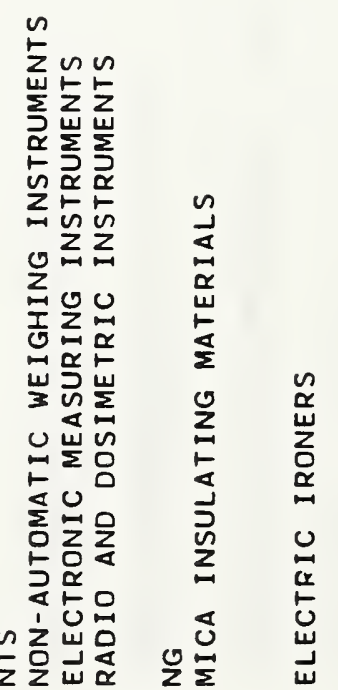

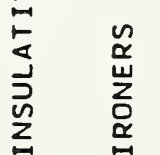

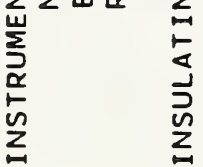

$\stackrel{n}{\longleftarrow}$

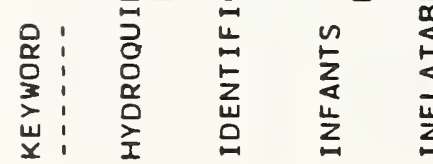

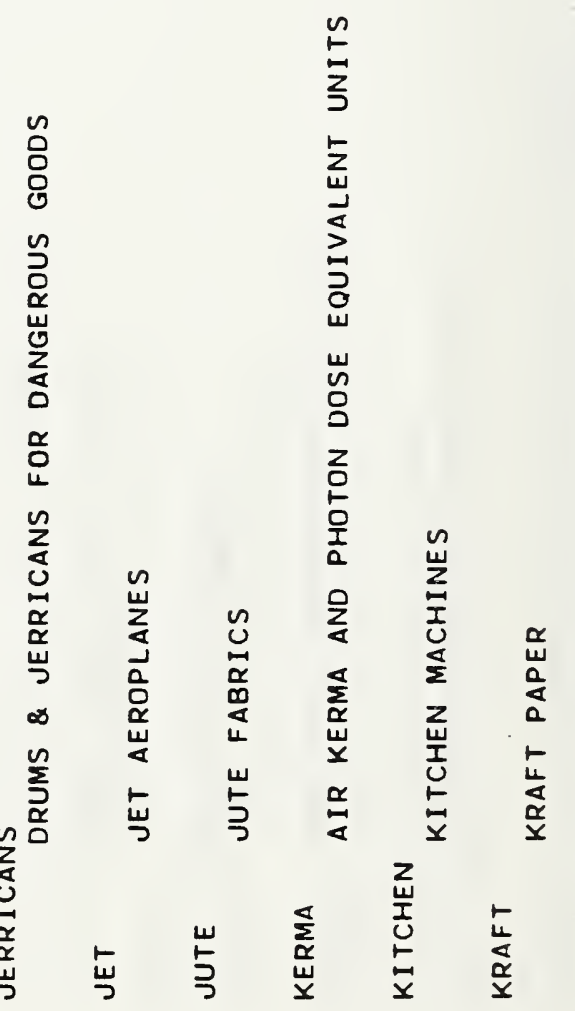


$\begin{array}{l:ll}\dot{2} & \\ z & & \\ z & & \infty\end{array}$

ڤ)

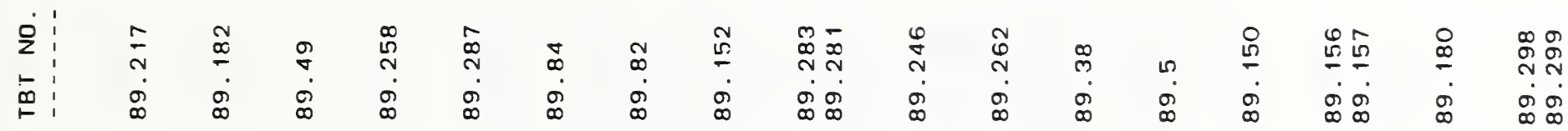

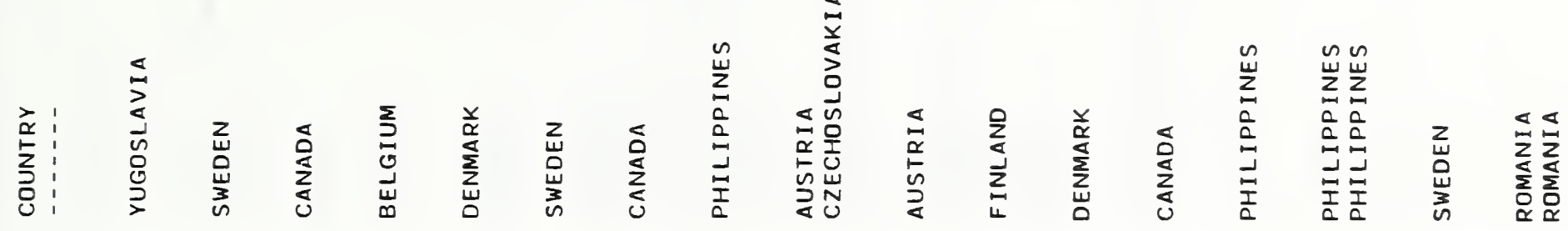

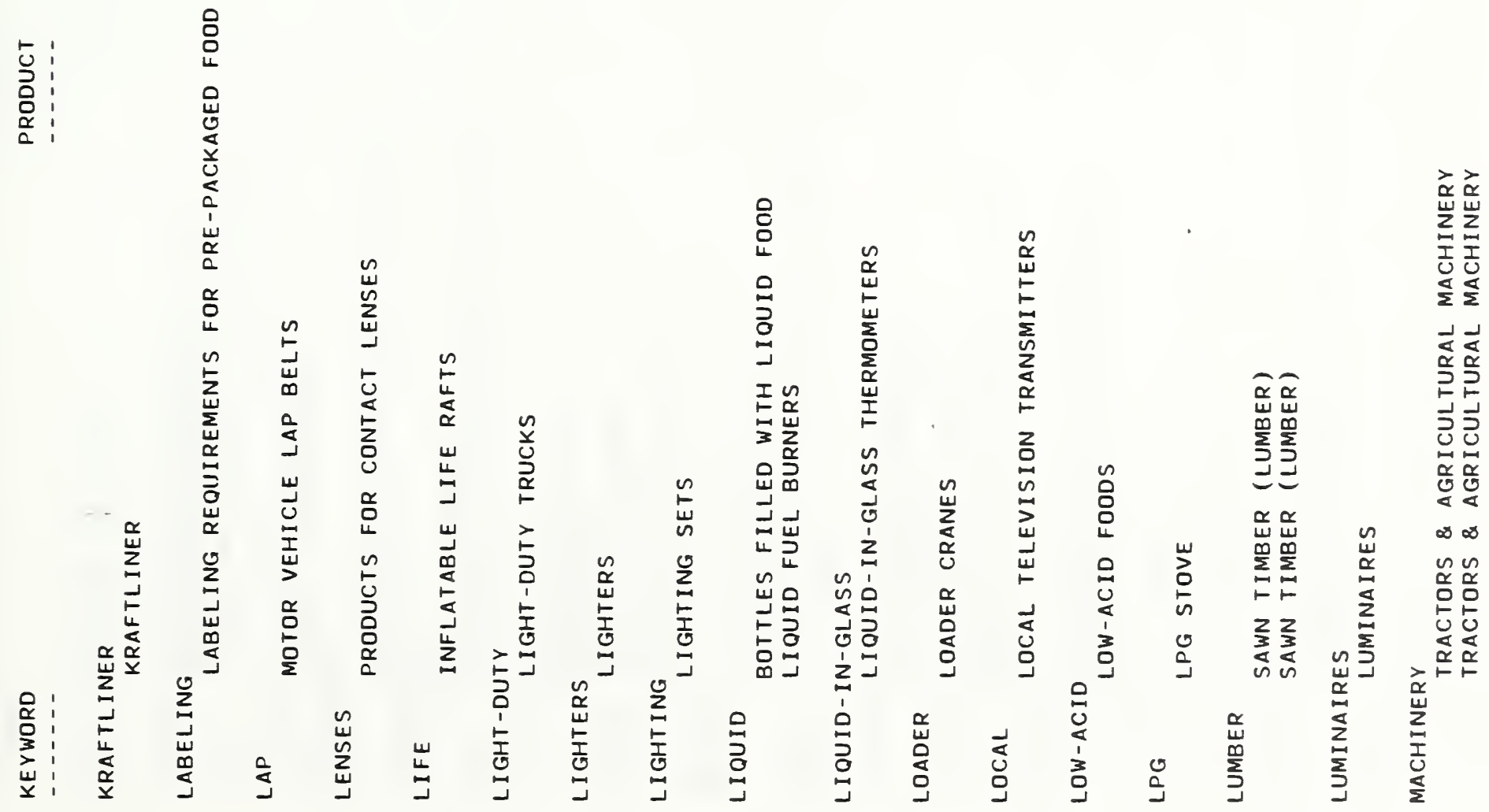




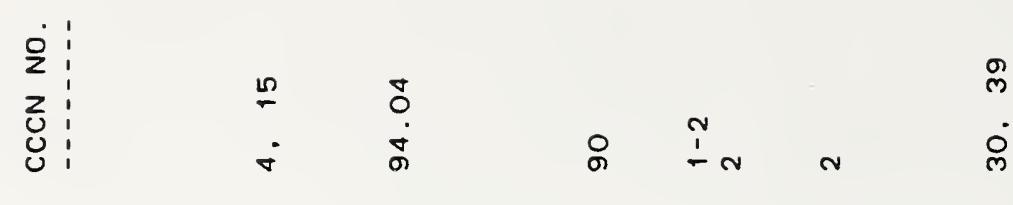

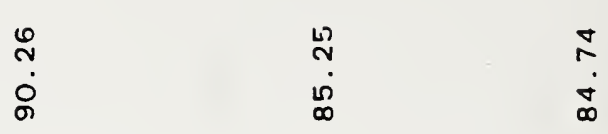

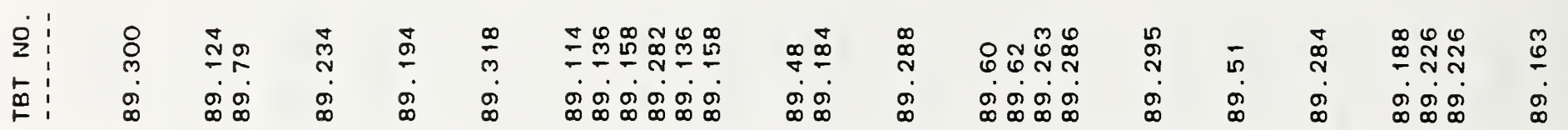

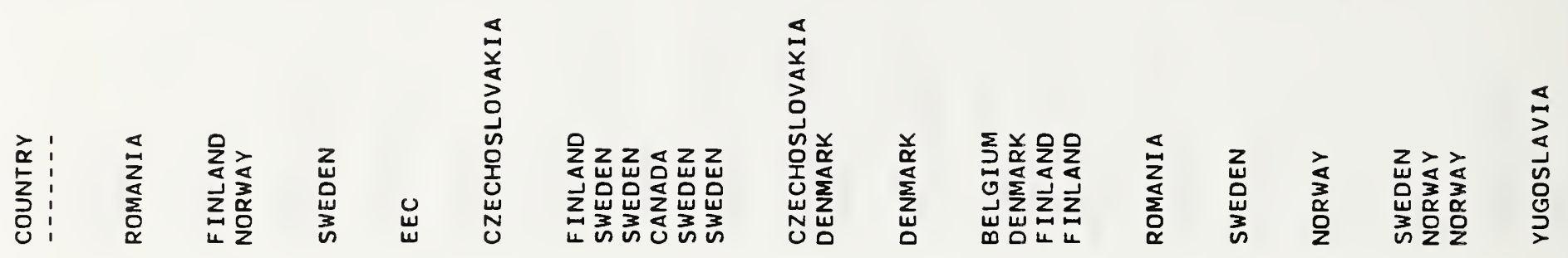

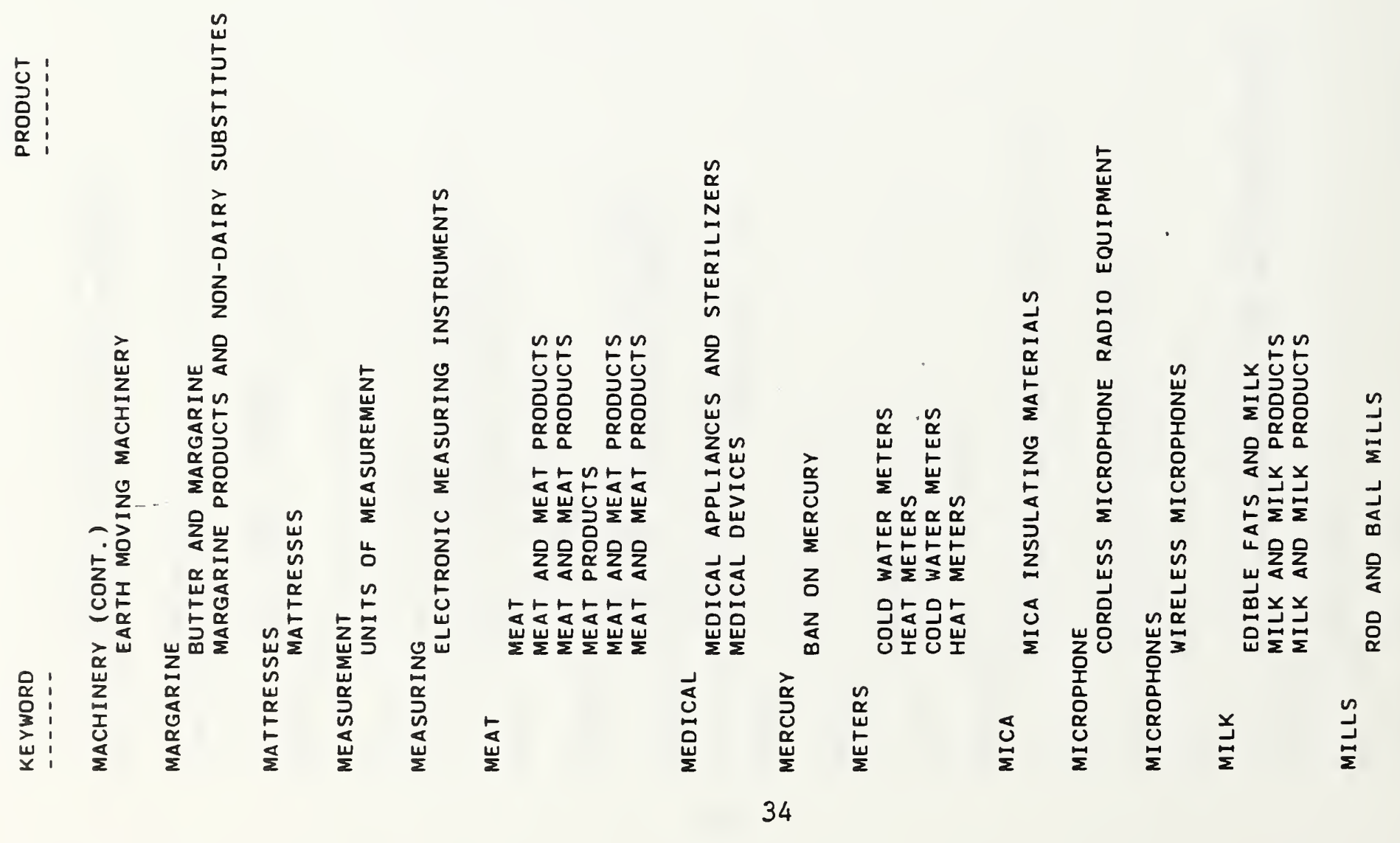




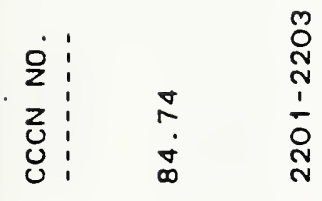

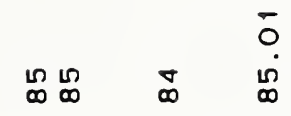

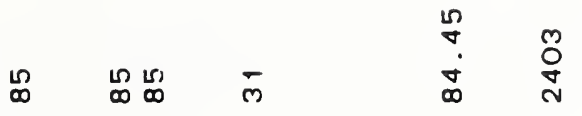

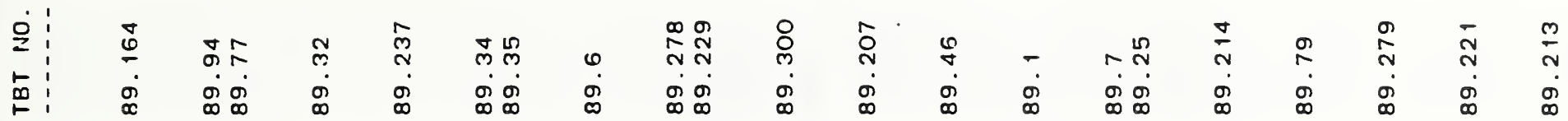

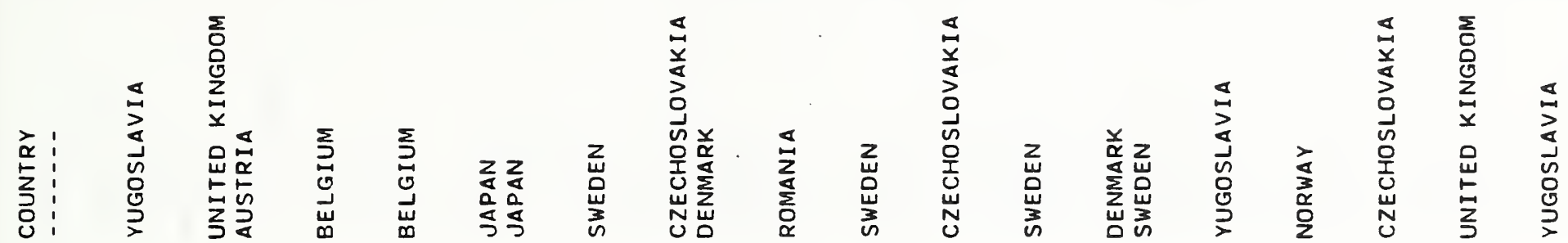

\begin{tabular}{l:c}
$\mathfrak{y}$ \\
\hdashline \\
\hdashline \\
\hdashline \\
\hdashline
\end{tabular}

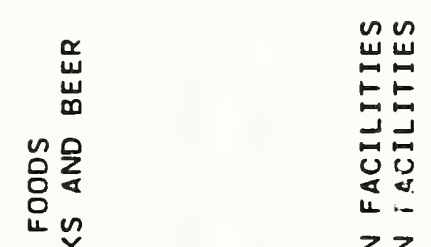

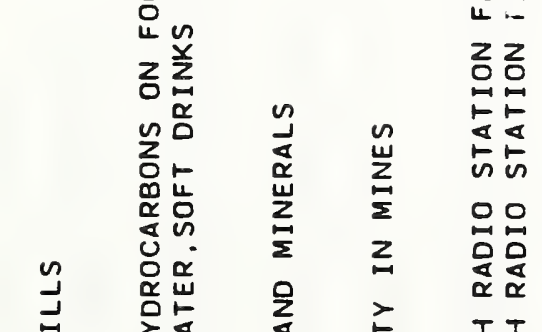

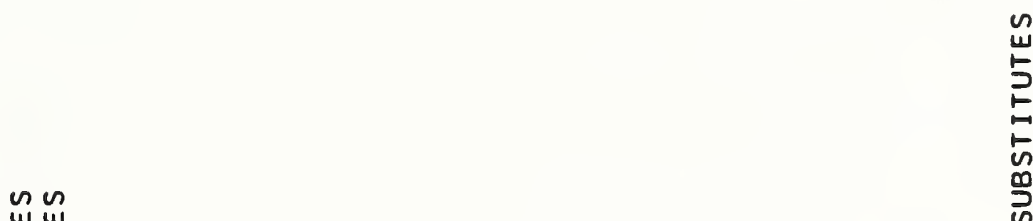

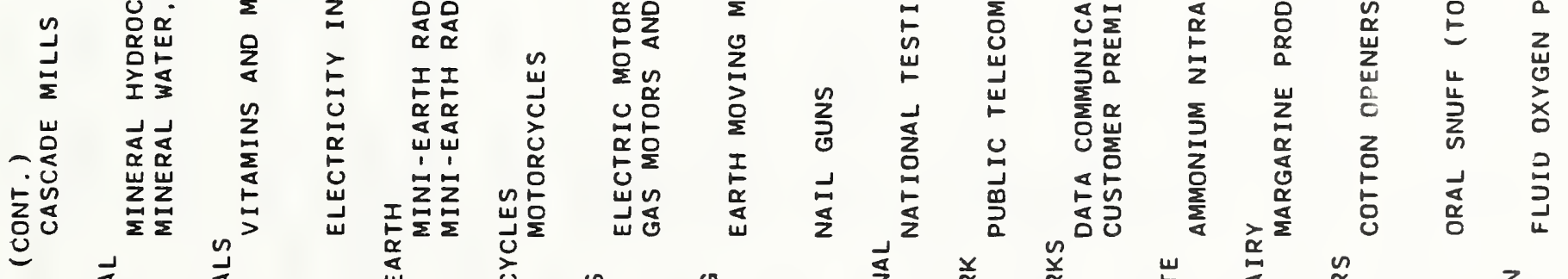

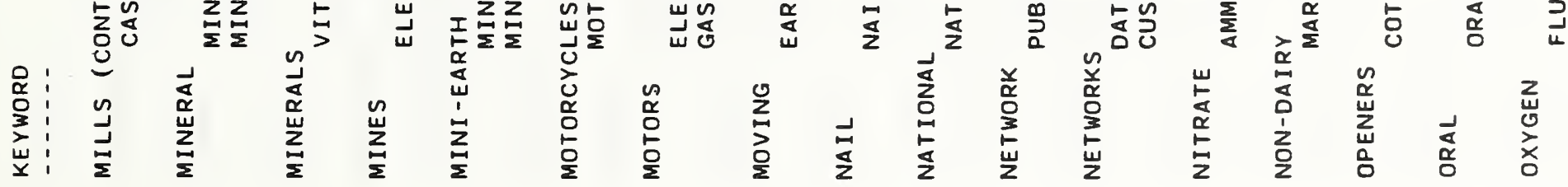




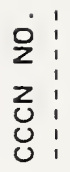

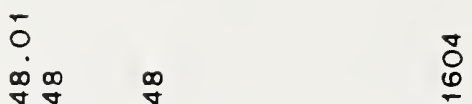

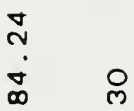

$\stackrel{5}{\stackrel{\infty}{\infty}}$

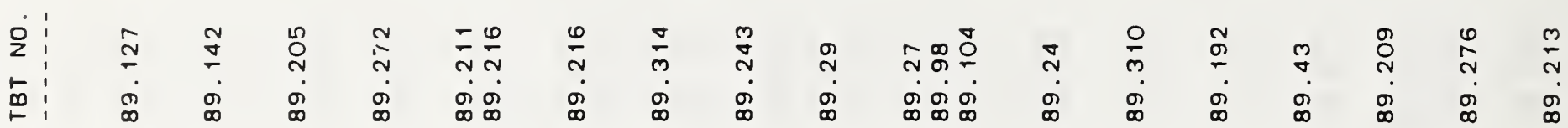

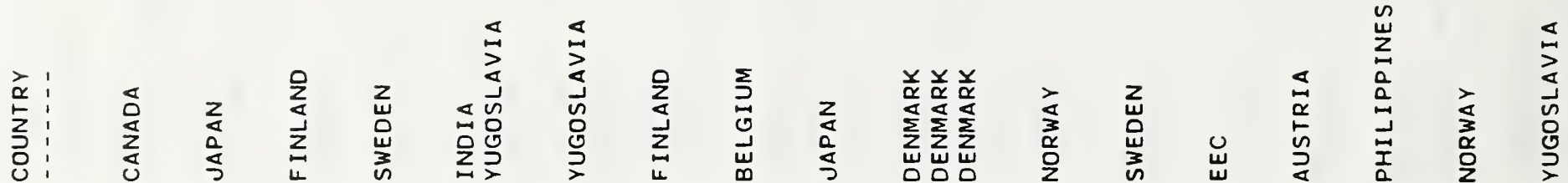

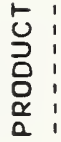

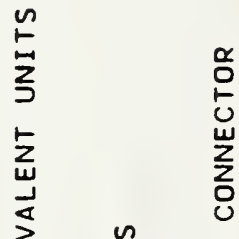

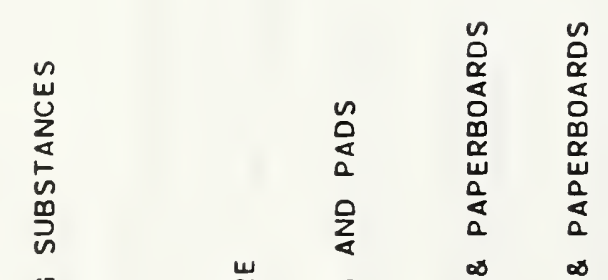

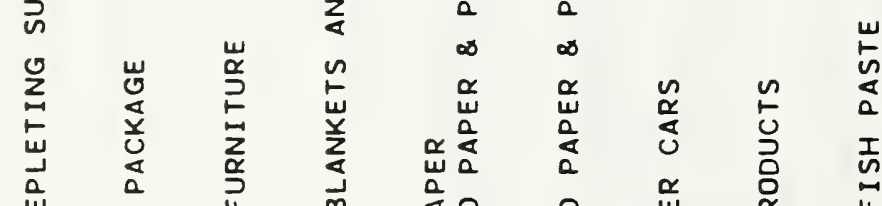

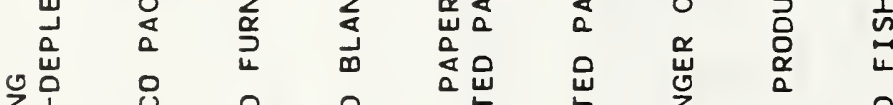

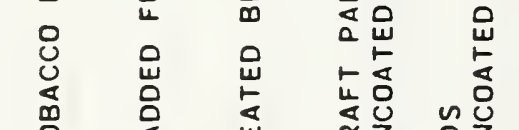

$\sum_{z}^{0} \frac{\alpha}{\alpha}$

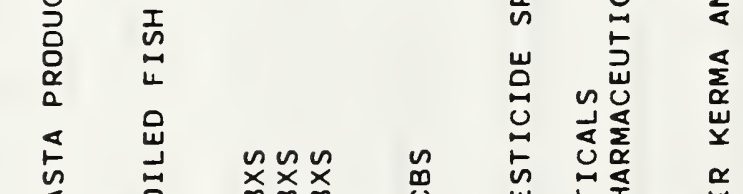

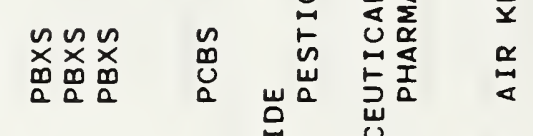

号

ㅁํㅁ

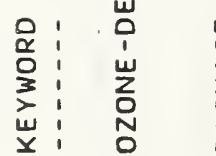

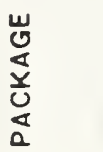

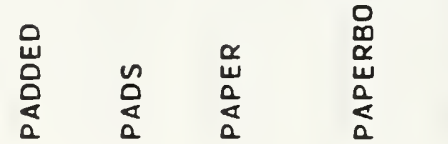

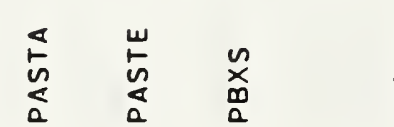

㩊

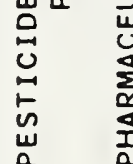

言粍

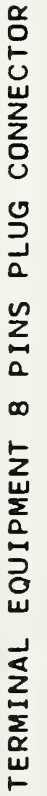

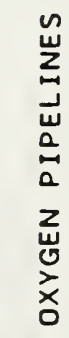

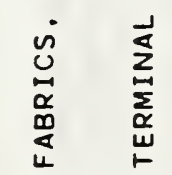

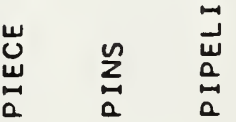




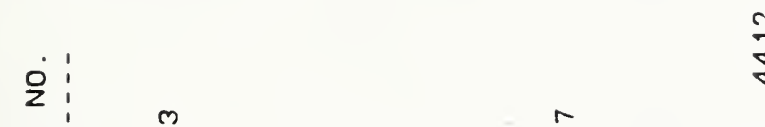

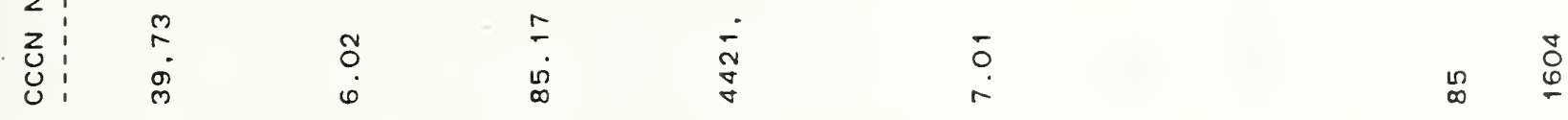

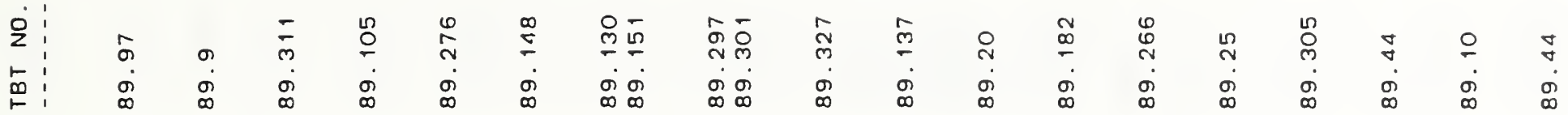

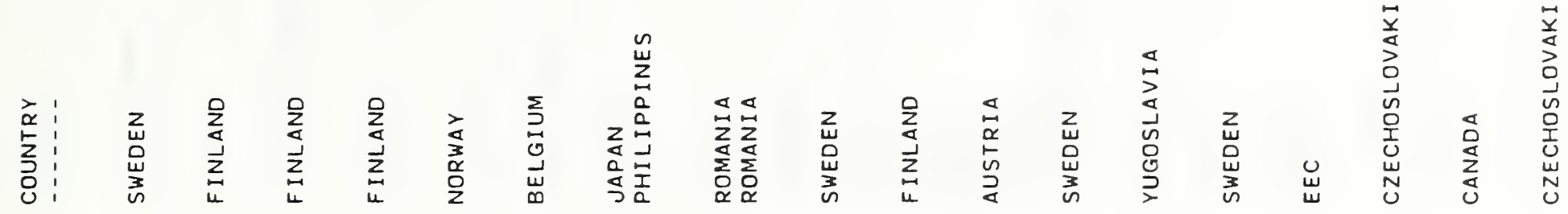

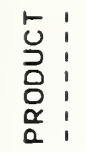

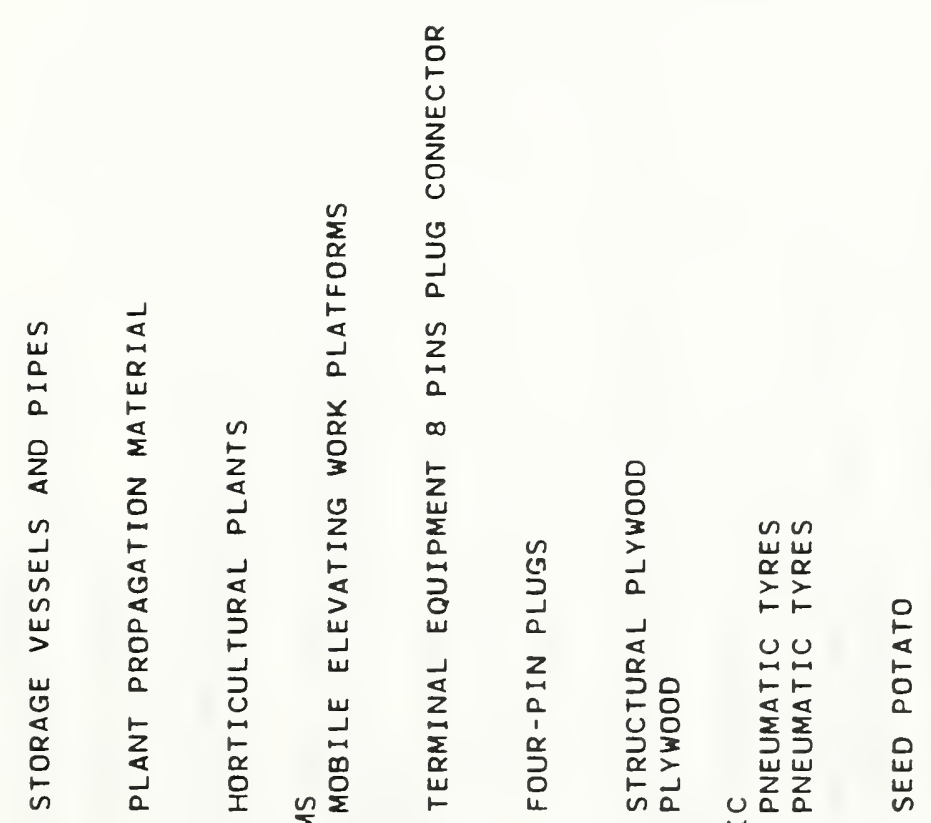

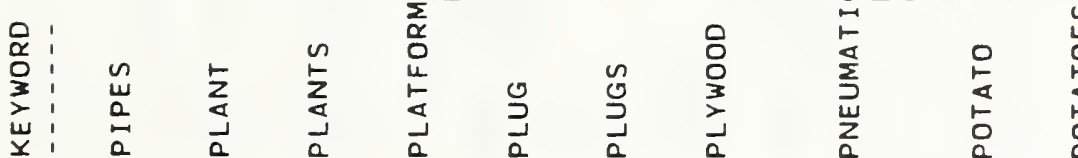

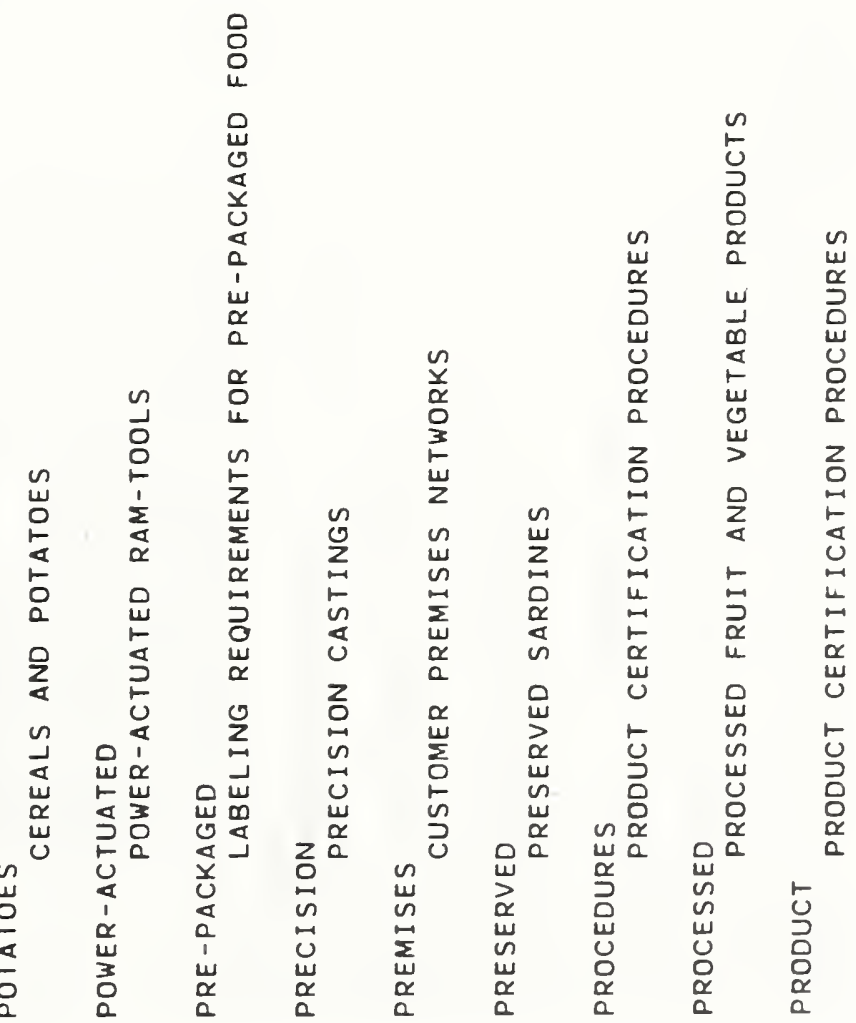




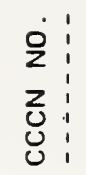

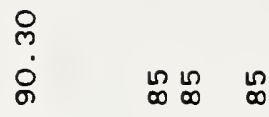

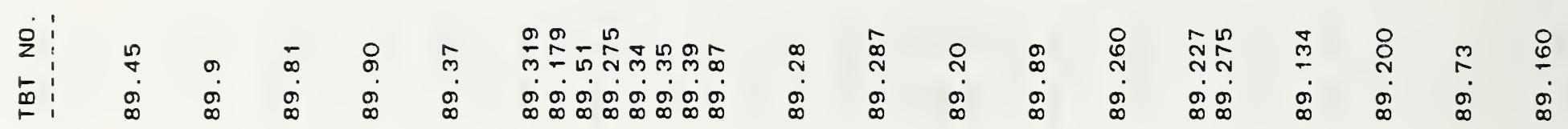

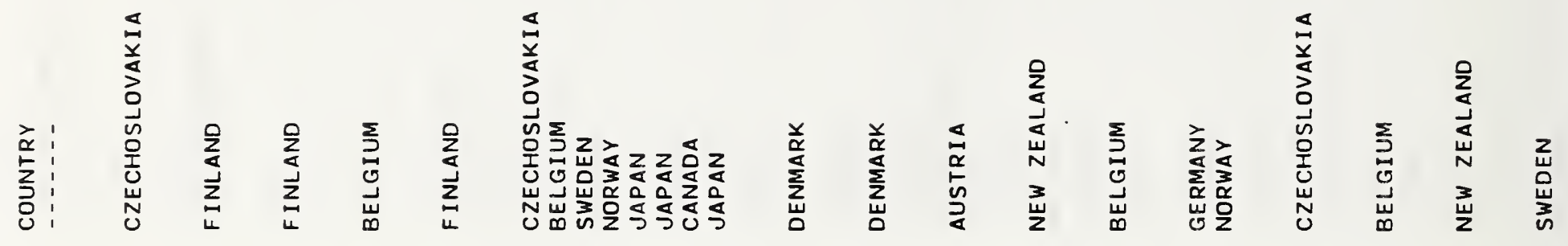

:

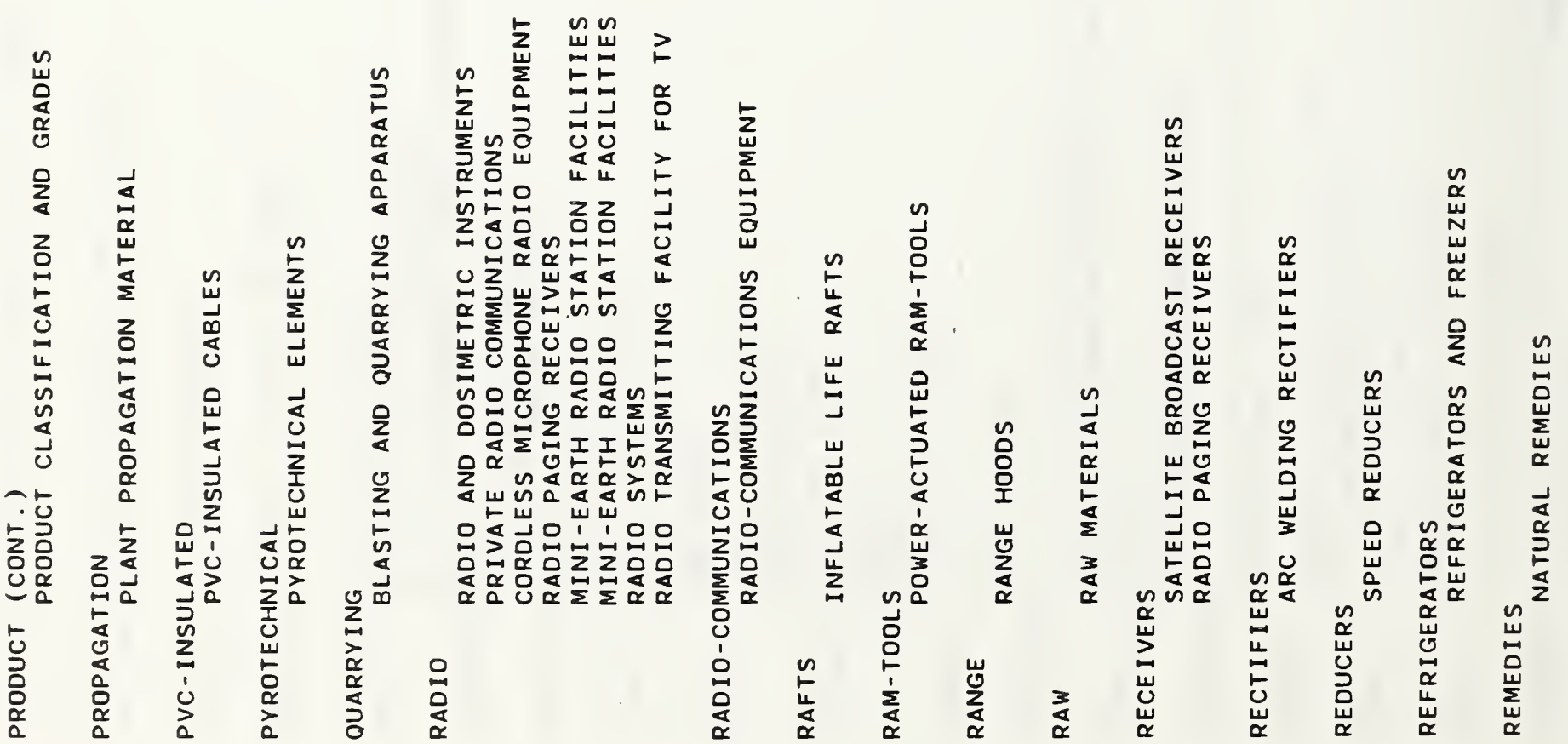


$\frac{1}{2}$

竞

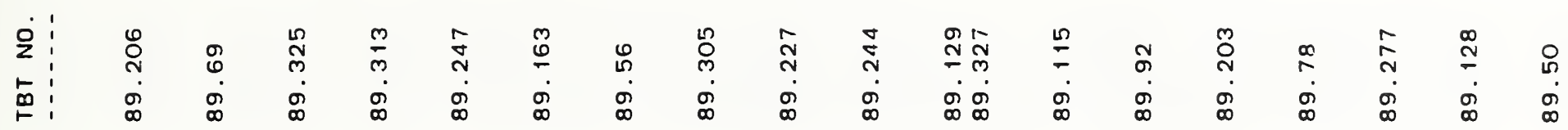

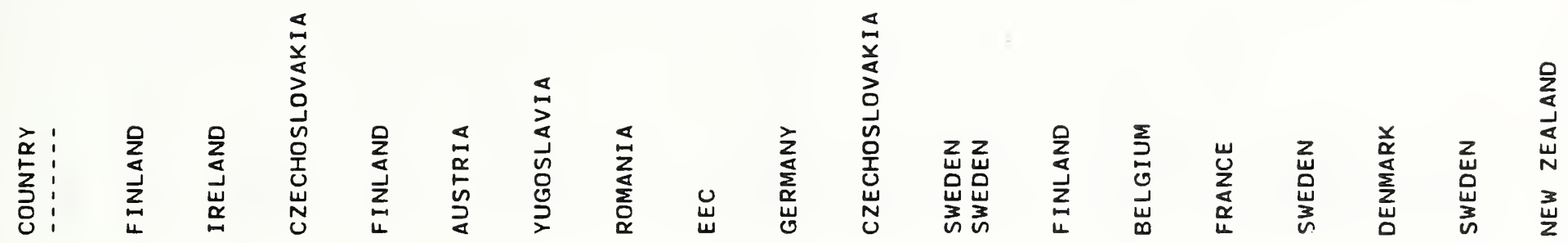

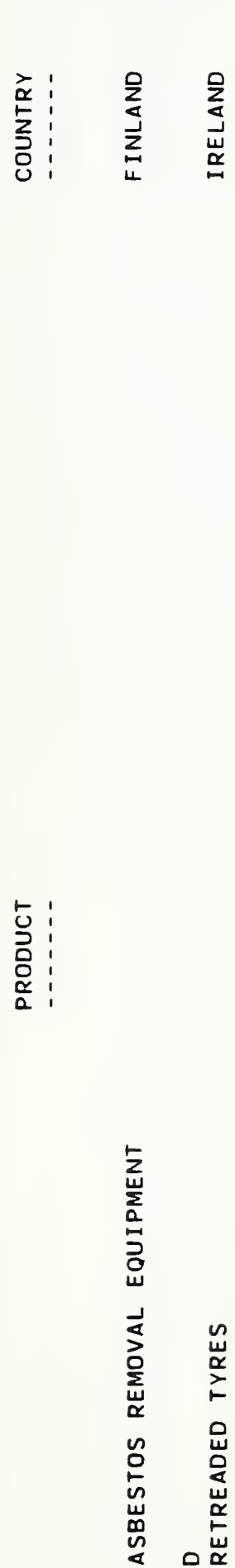




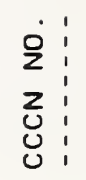

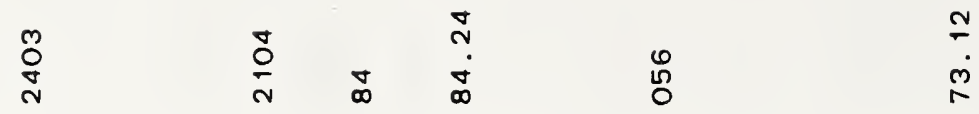

$\stackrel{n}{\stackrel{n}{n}}$

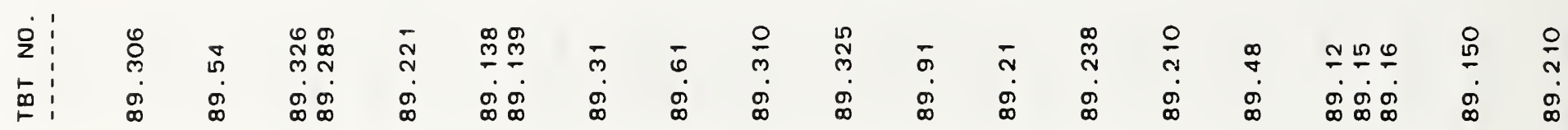

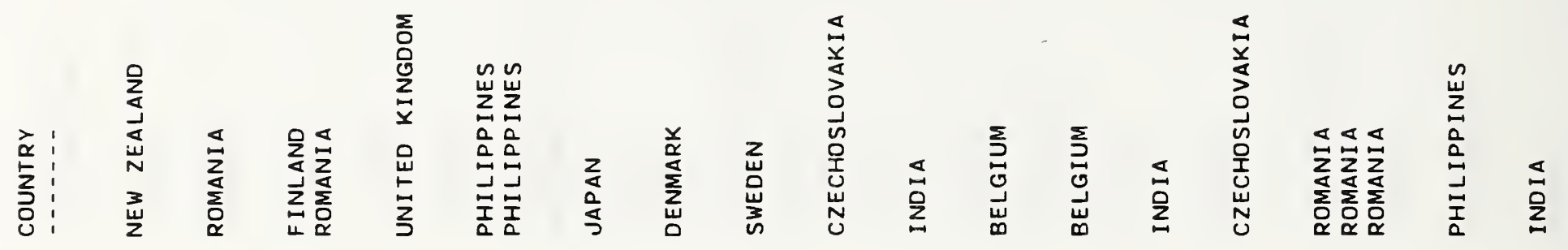

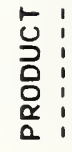

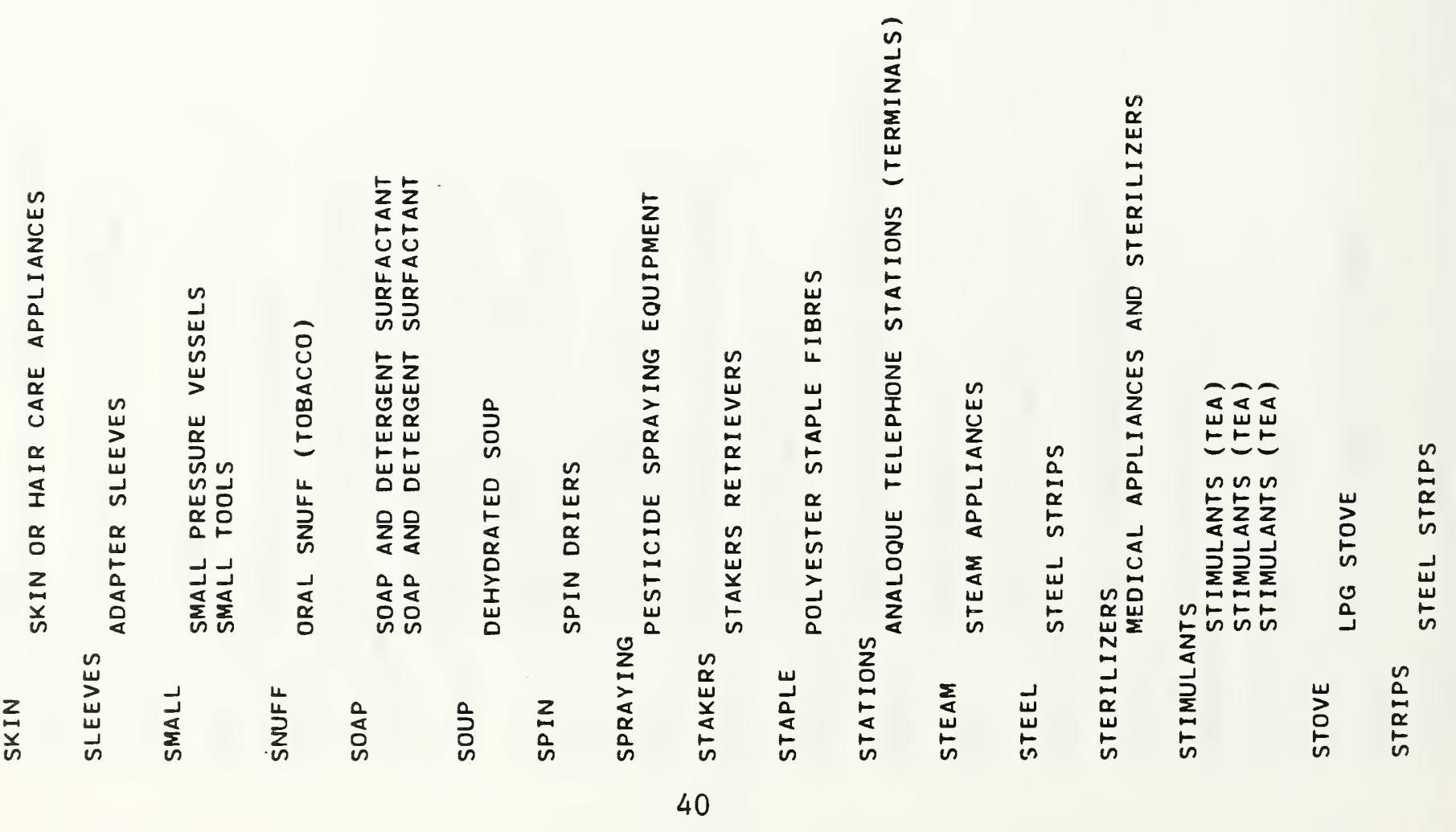




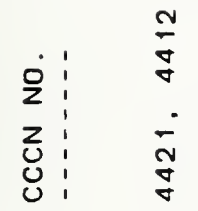

ڤ

$\stackrel{n}{\infty} \underset{\infty}{\stackrel{\infty}{\infty}}$

$\underset{\substack{0 \\ \infty}}{\stackrel{0}{0}}$

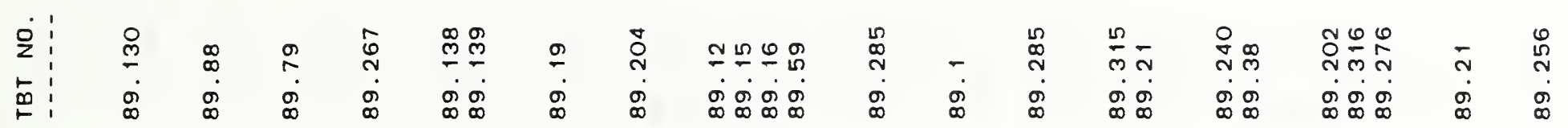

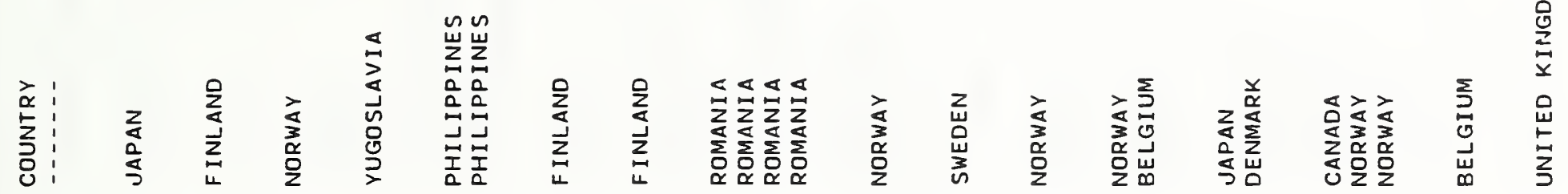

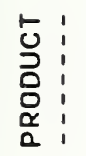
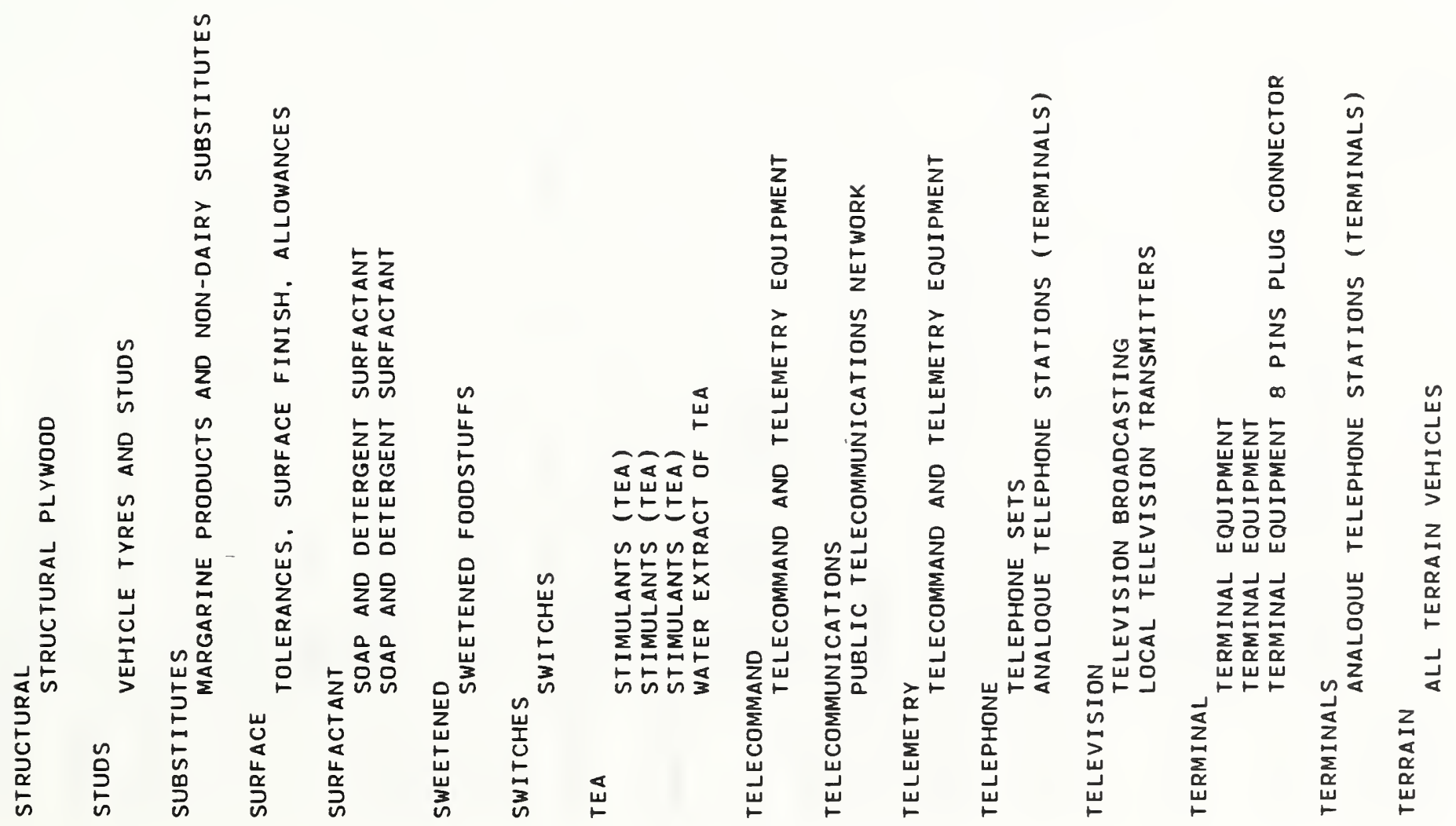


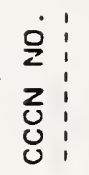

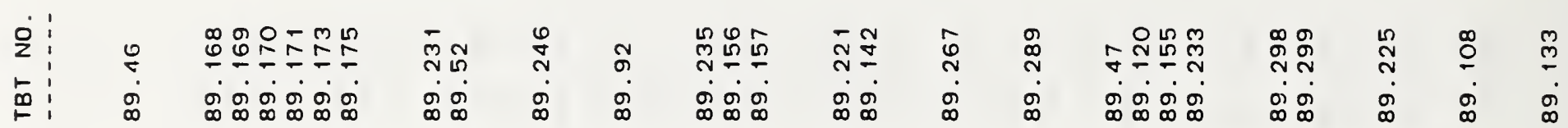

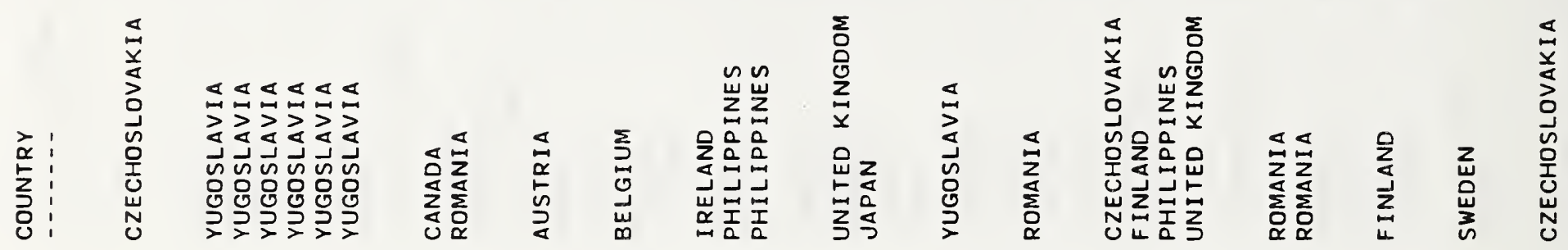

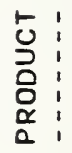

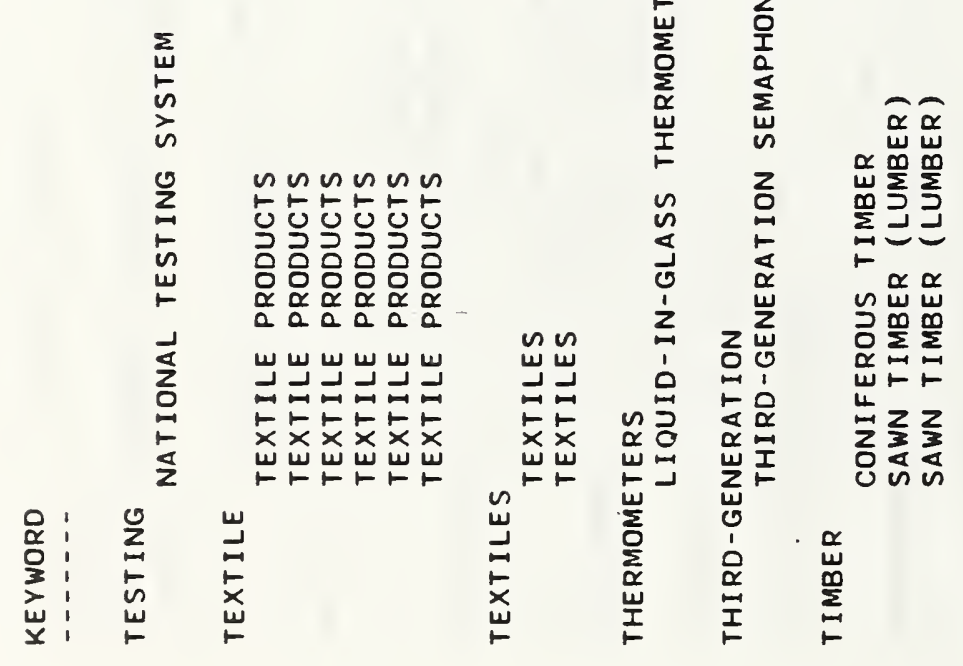



I?
$\stackrel{n}{\infty} \frac{1}{\infty} \infty$
ชิ

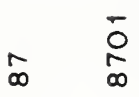

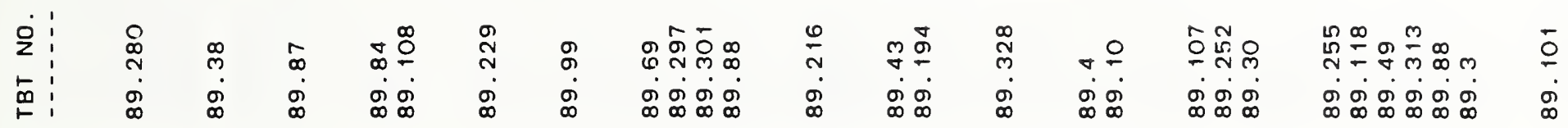

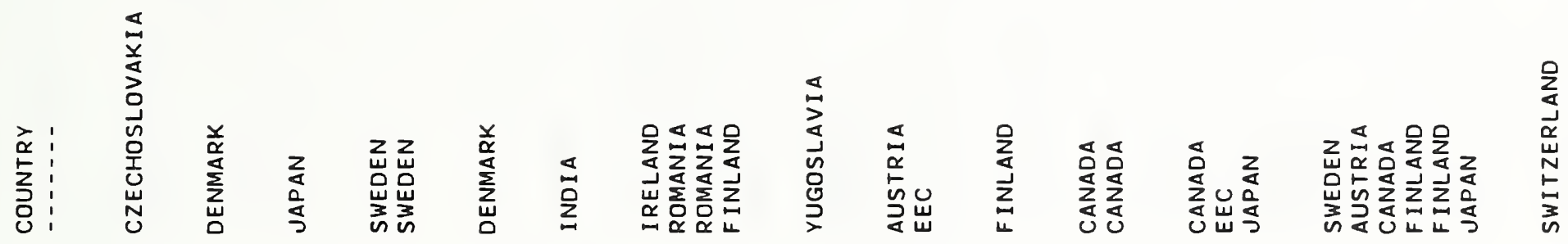

:

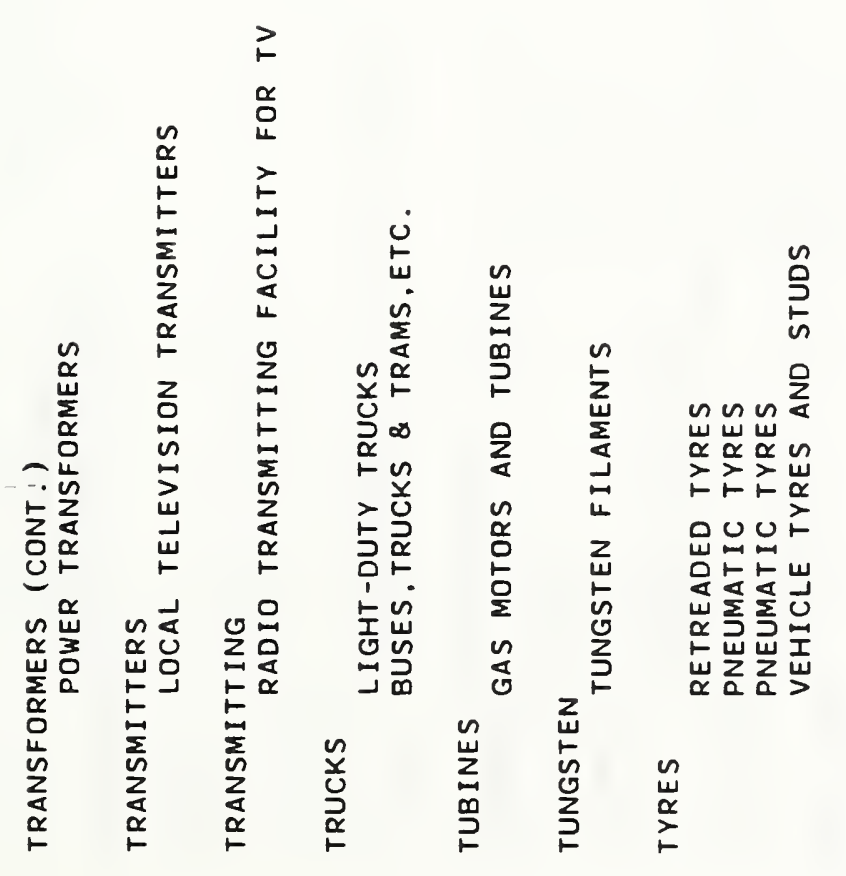

$\stackrel{n}{\llcorner}$

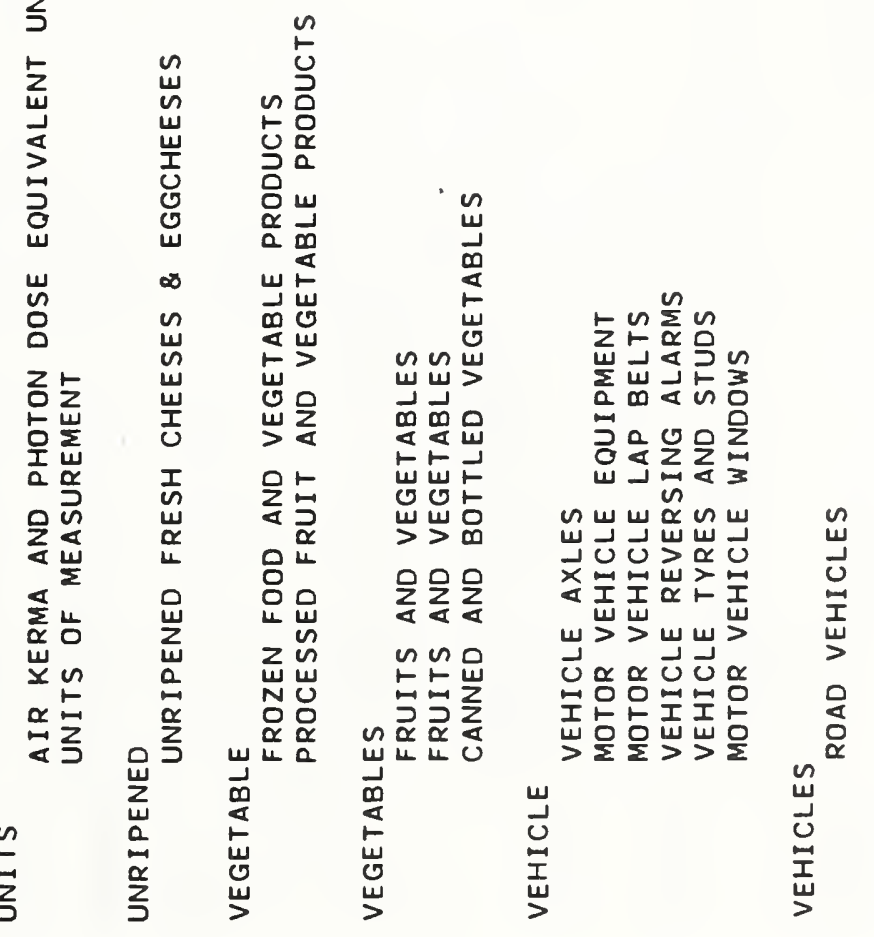


$\begin{array}{l:llll} & & \\ 2 & & & \\ z & 0 & 0 & 0 \\ 0 & 0 & 0 & 0\end{array}$

$\stackrel{\stackrel{n}{\sim}}{\infty} \quad \stackrel{\infty}{\infty}$

$\frac{0}{1}$

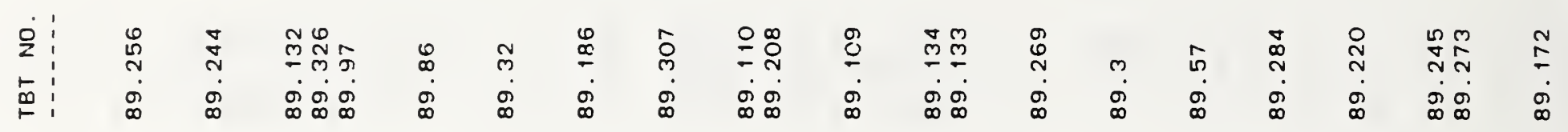

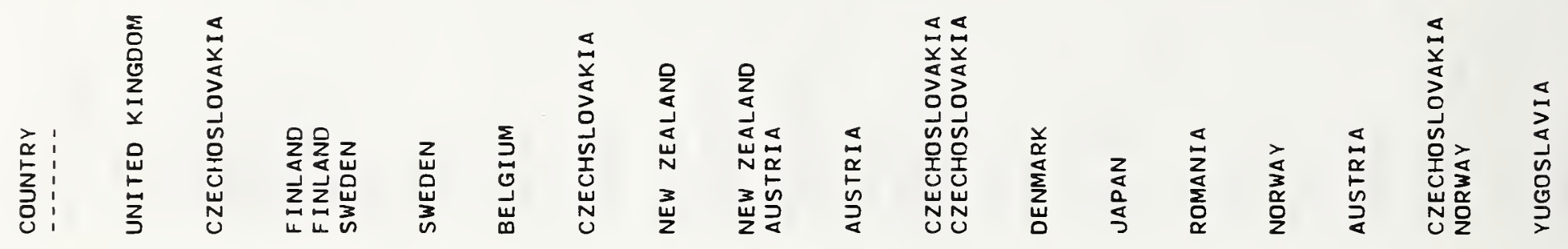

\begin{tabular}{l:c}
5 \\
\hdashline \\
\hdashline \\
\hdashline \\
\hdashline
\end{tabular}

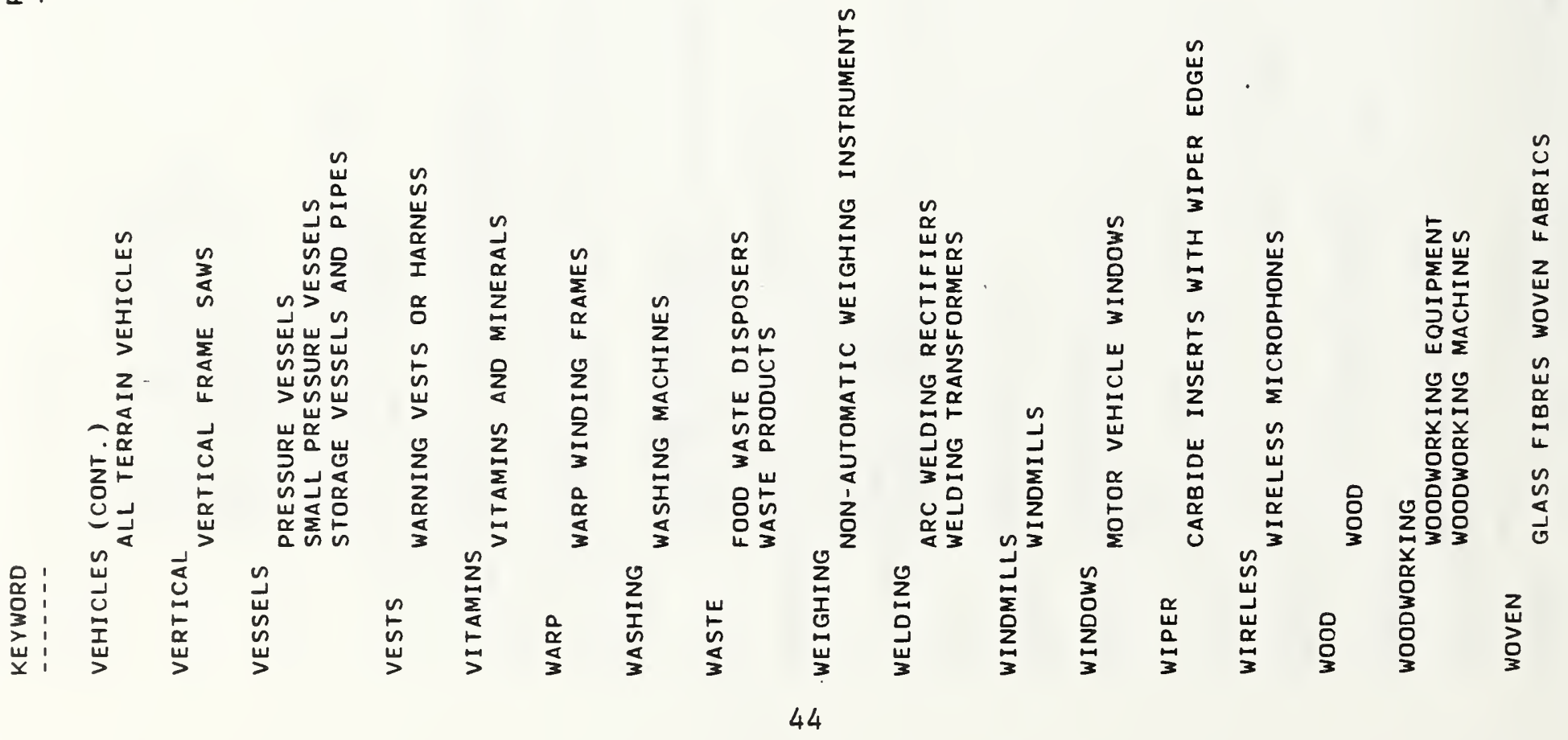




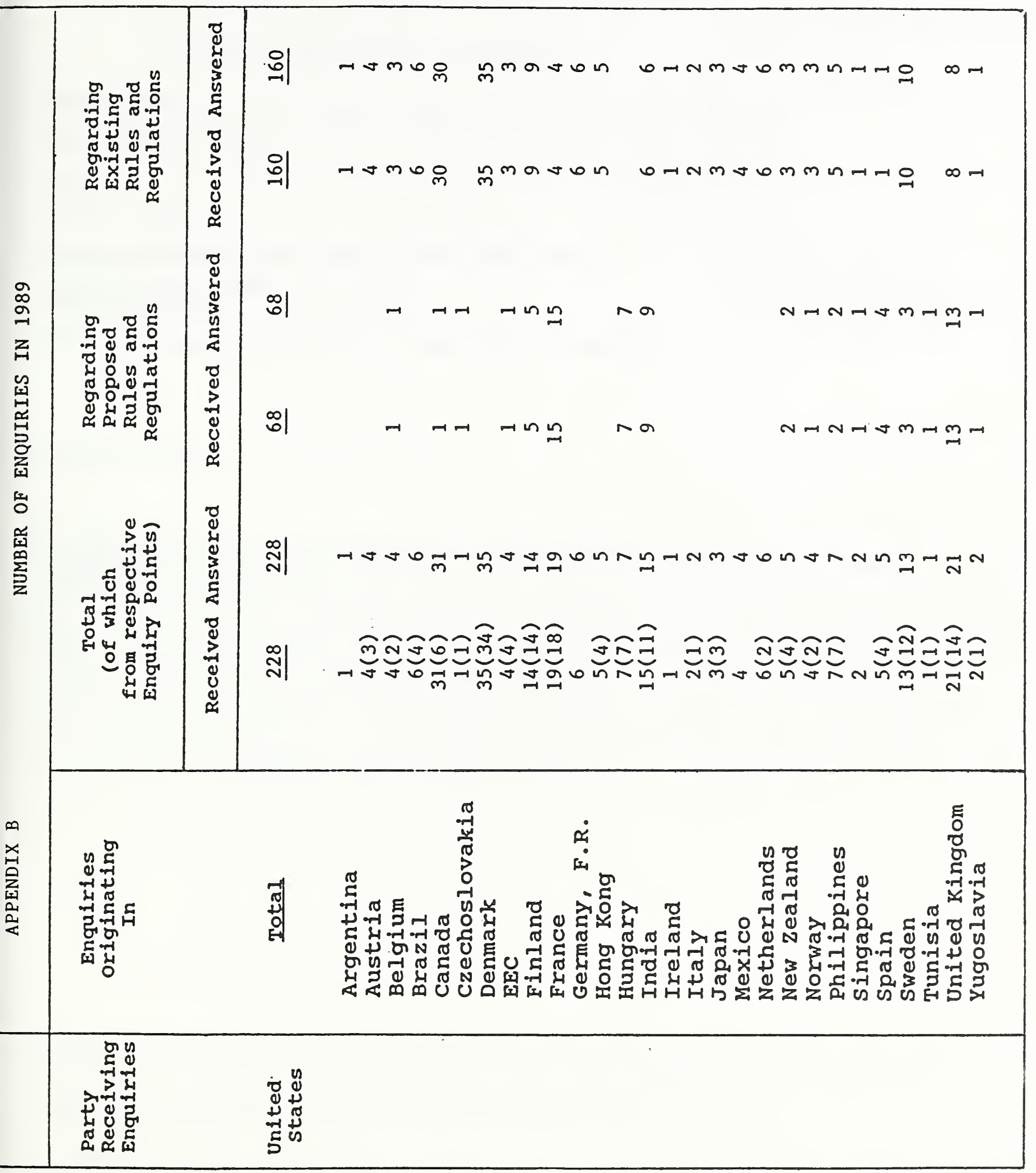





\begin{tabular}{|c|c|c|}
\hline \multirow[t]{4}{*}{$\begin{array}{l}\text { NIST-114A } \\
\text { (REV. 3-89) }\end{array}$} & \multirow{4}{*}{$\begin{array}{l}\text { U.S. DEPARTMENT OF COMMERCE } \\
\text { NATIONAL INSTITUTE OF STANDARDS AND TECHNOLOGY } \\
\text { BIBLIOGRAPHIC DATA SHEET }\end{array}$} & $\begin{array}{l}\text { 1. PUBLCATION OR REPORT NUMBER } \\
\text { NISTIR } 4314\end{array}$ \\
\hline & & PERFORMING ORGANIZATION REPORT NUMBER \\
\hline & & PUBUCATION DATE \\
\hline & & April 1990 \\
\hline
\end{tabular}
4. TITLE AND SUBTITLE
GATT STANDARDS CODE ACTIVITIES OF THE NATIONAL INSTITUTE OF STANDARDS
AND TECHNOLOGY - 1989
5. AUTHOR(S)
JoAnne R. Overman
6. PERFORMING ORQANIZATION (IF JOINT OR OTHER THAN NIST, SEE INSTRUCTIONS)
U.S. DEPARTMENT OF COMMERCE
NATIONAL INSTITUTE OF STANDARDS AND TECHNOLOGY
GAITHERSBURG, MD 20899
7. CONTRACT/GRANT NUMBER
8. TYPE OF REPORT AND PERIOD COVERED
Annual - 1989

9. SPONSORING ORGANIZATION NAME AND COMPLETE ADDRESS (STREET, CITY, STATE, ZIP)

10. SUPPLEMENTARY NOTES

DOCUMENT DESCRIBES A COMPUTER PROGRAM; SF-185, FIPS SOFTWARE SUMMARY, IS ATTACHED.

1. ABSTRACT (A 200-WORD OR LESS FACTUAL SUMMARY OF MOST SIGNIFICANT INFORMATION. IF DOCUMENT INCLUDES A SIGNIFICANT BIBUOGRAPHY OR LITERATURE SURVEY, MENTION IT HERE.)

This report describes the GATT Standards Code activities conducted by the Standards Code and Information Program, National Institute of Standards and Technology (NIST), for calendar year 1989. It also presents statistics covering the 10 years (1980 through 1989) of the Standards Code's implementation in the United States. NIST responsibilities include operating the U.S. GATT inquiry point for information on standards and certification activities and the technical office for non-agricultural products; notifying the GATT Secretariat of proposed U.S. Federal Government standards-based rules that might significantly affect trade; assisting U.S. industry with standards-related trade problems; and responding to inquiries about proposed foreign and U.S. regulations.

12. KEY WORDS (6 TO 12 ENTRIES; ALPHABETICAL ORDER; CAPITALIZE ONLY PROPER NAMES; AND SEPARATE KEY WORDS BY SEMICOLONS)

certification information; GAlT Standards Code; notifications; proposed foreign regulations; standards information; technical assistance

FOR OFFICIAL DISTRIBUTION. DO NOT RELEASE TO NATIONAL TECHNICAL INFORMATION SERVICE (NTIS).

ORDER FROM SUPERINTENDENT OF DOCUMENTS, U.S. GOVERNMENT PRINTING OFFICE, WASHINGTON, DC 20402.

ORDER FROM NATIONAL TECHNICAL INFORMATION SERVICE (NTIS), SPRINGFIELD, VA 22161

49

15. PRICE A03




